\title{
Mitral cells and the glucagon-like peptide 1 receptor: The sweet smell of success?
}

\author{
Enrico Bagnoli $^{1,2}$ (D) | Una FitzGerald ${ }^{1,2}$ (I)
}

${ }^{1}$ CÚRAM, Centre for Research in Medical Devices, National University of Ireland

Galway, Galway, Ireland

${ }^{2}$ Galway Neuroscience Centre, School of Natural Sciences, National University of Ireland Galway, Galway, Ireland

\section{Correspondence}

Una FitzGerald, Galway Neuroscience Centre, School of Natural Sciences, National University of Ireland Galway, Galway, Ireland.

Email: una.fitzgerald@nuigalway.ie

\section{Funding information}

Science Foundation Ireland; H2020 MSCA-ITN-2015 Marie Sklodowska-Curie Innovative Training Network, Grant/Award Number: Grant Agreement No. 676408; European Regional Development Fund, Grant/Award Number: 13/RC/2073

\begin{abstract}
The olfactory bulb (OB) is often affected at very early stages of neurodegenerative disorders, in the so-called "prodromal" phase. In Parkinson's disease (PD), olfactory disturbances appear years before motor symptoms arise. Additionally, pathological alpha-synuclein aggregates are found in olfactory regions before spreading to other areas of the brain. Being positioned at the frontier between the brain and a potentially hostile environment, could explain the particular vulnerability of the OB. Mitral cells (MCs), the principal projecting neurons of the olfactory system, are involved in the pathogenesis and in the prion-like progression of PD. They are affected by Lewy pathology and are thought to contribute to the axonal transport of misfolded alphasynuclein to other regions of the brain. Here, we first describe the main markers reported to distinguish MCs from other olfactory neurons. We focus on the glucagon-like peptide 1 receptor (GLP-1R), a membrane protein specifically expressed in MCs. After summarizing OB pathology, we explore the idea of targeting specifically MCs with GLP-1 or its analogues. Exenatide has shown great promise as a neuroprotective and neurorestorative agent and has been used in a clinical trial for clinical PD. Since GLP-1R activation has the ability to mitigate many facets of prodromal PD pathology, we postulate that once a robust biomarker is in place that is capable of identifying individuals in the prodromal phase of PD, homing in on GLP-1R could assist in deferring, or eradicating to a significant degree, the clinical manifestation of this debilitating human disorder.
\end{abstract}

\section{K E Y W O R D S}

early treatment, GLP-1R, glucagon-like peptide receptor, olfactory bulb, Parkinson's disease, pro-dromal Parkinson's disease

\begin{abstract}
Abbreviations: 6-OHDA, 6-hydroxydopamine; AD, Alzheimer's disease; AKT, protein kinase B; AON, anterior olfactory nucleus; APP, amyloid precursor protein; BAX, Bcl-2-associated X protein; BBB, blood-brain barrier; Bcl-2, B-cell lymphoma 2; BDNF, brain-derived neurotrophic factor; cAMP, cyclic adenosine monophosphate; CNS, central nervous system; CREB, cAMP response element-binding protein; DPP-IV, dipeptidyl peptidase IV; EPL, external plexiform layer; ERK, extracellular signal-regulated kinase; FOXO1, forkhead box protein O1; GCL, granule cell layer; GDNF, glial-derived neurotrophic factor GL: glomerular layer; GLP-1, glucagon-like peptide 1; GLP-1R, glucagon-like peptide-1 receptor; GSK3B, glycogen synthase kinase 3 beta; IDE, insulin-degrading enzyme; IND, intranasal delivery; IPL, internal plexiform layer; LB, Lewy body; LN, Lewy neurites; MAPK, mitogen-associated protein kinase; MCL, mitral cell layer; MC, mitral cell; MPTP, 1-Methyl-4-phenyl-1,2,3,6-tetrahydropyridine; mTOR, mammalian target of rapamycin; NF- $\mathrm{BB}$, nuclear factor kappalight-chain-enhancer of activated B cells; NGF, nerve growth factor; OB, olfactory bulb; OSN, olfactory sensory neuron; Pcdh21, protocadherin 21; PI3K, phosphatidylinositide 3-kinases; PKA, protein kinase A; PPG, pre-pro-glucagon; RMS, rostral migratory stream; ROS, reactive oxygen species; SGZ, subgranular zone; SVZ, subventricular zone; Tbr1, T-box brain 1; Tbr2, T-box brain 2; Tbx21, T-box protein 21; TC, tufted cell; TH, tyrosine hydroxylase.
\end{abstract}

Edited by Prof. Paul Bolam. Reviewed by Thomas Foltynie and DA Fadool.

All peer review communications can be found with the online version of the article. 


\section{I THE OLFACTORY BULB}

The olfactory bulb (OB) is the area of the brain devoted to the first processing of smell and olfaction in the central nervous system (CNS). These oval paired structures are located at the base of the brain above the cribriform plate and they consist of concentric layers of neurons and support cells (Doty, 2001). The cytoarchitecture of the OB is evolutionary well-preserved between mammals; the human one is slightly less complex than that found in rodents, but shares the fundamental six-layer organization (Duda, 2010). Below, we briefly describe the organization and structure of OB neurons, but recommend the recent review by Kosaka and Kosaka (2016) for a more comprehensive insight into the neural circuitry.

\section{1 | The anatomy of the $\mathrm{OB}$}

Each OB is innervated by olfactory sensory neurons (OSNs), bipolar neurons whose dendrites are capped by immotile cilia responsible for odourant reception. These neurons are unique as they are continuously replaced by basal stem cells in a perpetual cycle of growth, degeneration, and replacement. More interestingly, olfactory neurons are the only primary afferent neurons to occupy a surface epithelium (Fitzgerald, Gruener, $\&$ Mtui, 2007). The unmyelinated axons of OSNs fasciculate in bundles to cross the cribriform plate, then disperse in the $\mathrm{OB}$ to form the olfactory nerve layer (ONL). They finally project into discrete spheres of nerve tissue called glomeruli where they form synapses with mitral cells (MCs), tufted cells (TCs), and several different types of interneurons, including periglomerular and superficial short-axon cells. OSNs expressing the same odour-receptor proteins project into two or a very few glomeruli; the glomerulus is thus the basic coding unit for olfactory information (Masurkar \& Chen, 2009).

A packed layer of neuropil, known as the external plexiform layer (EPL), is juxtaposed with the glomerular layer. The EPL contains the soma of tufted cells and interneurons, but it is mainly occupied by secondary dendrites of mitral and tufted cells and apical dendrites of granule cells. The dendro-dendritic interaction between these cells is responsible for the lateral inhibition of nonactivated mitral cells and the amplification of sensory signals (Kosaka \& Kosaka, 2016).

Mitral cell bodies occupy a narrow deeper layer called the mitral cell layer (MCL) and are located just above the internal plexiform layer (IPL), which contains collaterals of MCs and TCs.

The large granule cell layer (GCL) is the innermost and most densely populated structure of the OB. It is formed by small axonless interneurons, the granule cells, whose primary dendrites project into the EPL (Ruberte, Navarro, König, \& Puelles, 2017). Granule cells are continuously regenerated in adulthood in the subventricular zone (SVZ), reaching the $\mathrm{OB}$ through the rostral migratory stream (RMS) where they migrate radially in the GCL to integrate into the olfactory circuitry. The overall structure and circuitry of the OB is summarized in Figure 1.

\section{2 | Classification of Mitral and Tufted cells}

Mitral and tufted cells are the principal projection neurons of the $\mathrm{OB}$ and constitute one of the first processing platforms for sensory information (Shepherd, Chen, \& Greer, 2013). Odourant signals are preprocessed in the glomerulus and then propagated in the EPL through mitral and tufted cell dendrites before reaching the olfactory cortex. As these two types of cell share many morphological and physiological properties, and because in other well-studied organism such as Drosophilia or Teleost they are not separated, in many studies they have been categorized as mitral/tufted cells (Bargmann, 2006; Satou, 1990). However, in mammals, mitral and tufted cells constitute separate neuronal populations with many important differences, as listed below.

The soma of MCs are located in the MCL while the cell bodies of TCs are sparsely distributed across the EPL and are rarely found next to each other. MCs are the largest neurons of the olfactory circuitry, with somas that normally exceed $20 \mu \mathrm{m}$. During brain development, they are generated between embryonic day 10 and 13 . The smaller TCs, with a diameter of around $15 \mu \mathrm{m}$, are born later, between embryonic days 13 and 16, supporting the Hinds' concept of "larger cells before smaller ones" during OB development (Hinds, 1968; Imamura, Ayoub, Rakic, \& Greer, 2011).

Mitral and tufted cells have different lateral and apical projecting targets, with MCs dispersedly projecting into the whole olfactory cortex, while TCs have focal targets only in the anterior olfactory cortex. The differences in intrabulbar dendritic and axonal characteristics determined following single cell staining have enabled the categorization not only of these two different cell populations, but also of their subclasses (Ezeh, Wellis, \& Scott, 1993; Kishi, Mori, \& Ojima, 1984; Macrides \& Schneider, 1982; Orona, Rainer, \& Scott, 1984). More recent studies have highlighted how MCs and TCs fire during opposing phases of the respiratory and sniffing cycles, with MCs responding later than TCs (Fukunaga, Berning, Kollo, Schmaltz, \& Schaefer, 2012; Igarashi et al., 2012). TCs have also been shown to have a lower threshold for induction of an action potential after stimulation of sensory neurons (Ezeh et al., 1993).

Despite the aforementioned functional/physiological properties that differentiate the two cell populations, MCs and TCs share many molecular markers, often making their distinction challenging, particularly in studies where the cell morphology or location is lost, for example during flow cytometry or in dissociated cultures. The reported 


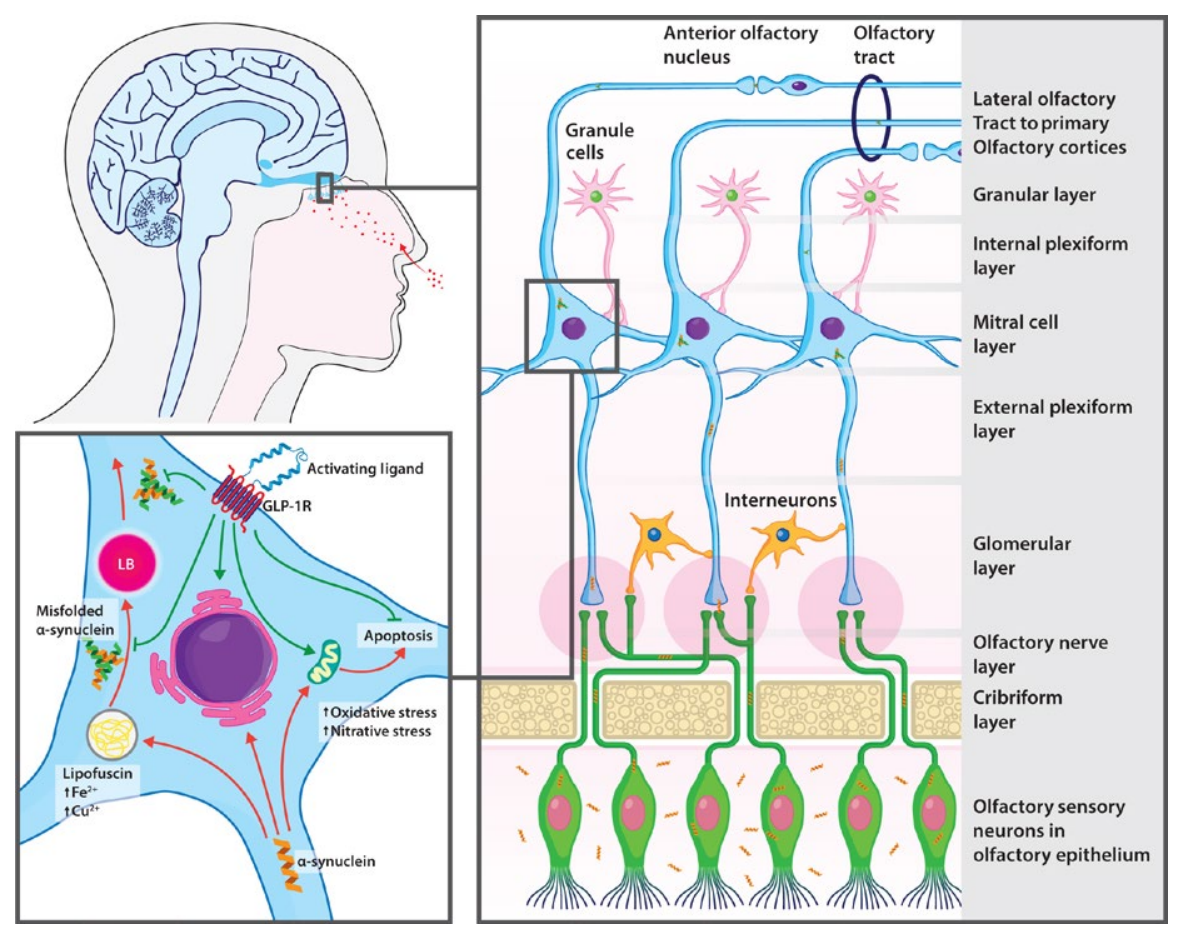

F I G U R E 1 Mitral cell targeting concept. Olfactory receptor neurons (green, bottom of RH panel) are naturally rich in alpha-synuclein, which may pass in its normal conformation to MCs. Following the entry of toxins from the environment (red, top LH panel), possibly leading to pathological stresses such as oxidative, nitrative or endoplasmic reticulum stress and metal deposits in lipofuscin granules, mis-folding and aggregation of a-synuclein may be provoked. Misfolded/aggregated a-synuclein may then be propagated to connected brain regions such as the AON (initially) and primary olfactory cortices (later). The activation of the GLP-1R, using GLP-1 analogues (bottom LH panel), could block the formation of protein aggregates, improve mitochondrial function and inhibit cellular stresses, ultimately preventing the pathological spreading of $\alpha$-synuclein and halting PD

cell-specific markers that have been used successfully to distinguish MCs and TCs from other neurons, belong to three different protein families: T-box, protocadherin and gut hormones. The main findings regarding these specific markers are discussed below and are summarized in Table 1.

Members of the T-box family of transcription factors fulfil pivotal roles during development including cell-fate decision, differentiation, and organogenesis of different tissues such as the brain (Wilson \& Conlon, 2002). One subfamily of the T-box gene family is the T-box brain 1 (Tbr1) family, consisting of Tbr1, T-box brain 2 (Tbr2) (or Eomes), and T-box protein 21 (Tbx21) (or T-bet) (Papaioannou, 2014), all of which are found within MCs and TCs at different developmental stages in the OB. While the expression of Tbx21 is highly specific for mitral and tufted cells, Tbr1- and Tbr2-positive cells are found in other brain regions e.g., the cortex and hippocampus and in juxtaglomerular cells in the OB (Méndez-Gómez et al., 2011; Mihalas \& Hevner, 2017; Mitsui, Igarashi, Mori, \& Yoshihara, 2011). Tbr1 has been shown to regulate neural stem cell (NSC) differentiation in the OB, driving cells towards a neuronal or oligodendrocyte fate and inhibiting the formation of astrocytes. Thus, Tbr1 has been proposed as a valid candidate in neuroregeneration studies (MéndezGómez et al., 2011). From embryonic day 12.5, when the generation of MCs is maximal, Tbr1 and Tbr2 are highly expressed, while Tbx 21 is first seen after embryonic day 14.5 only in the anterior olfactory nucleus (AON) and after embryonic day 16 its expression increases in MCs and TCs, with only a slight decrease in adulthood (Faedo et al., 2002; Mihalas \& Hevner, 2017). Tbr1 and Tbr2 can thus be seen as markers of all glutamatergic olfactory neurons, including mitral, tufted and some glomerular cells, particularly during development (Brill et al., 2009; Kahoud, Elsen, Hevner, \& Hodge, 2014; Winpenny et al., 2011). Tbx21 is instead more restricted and selective to the mitral and tufted cell populations.

Protocadherins are part of the cadherin family, a group of proteins involved in calcium-dependent cell-to-cell adhesion with important functions in the nervous system (for a complete review see (Hirano \& Takeichi, 2012)). The first protocadherin described in the olfactory bulb is KIAA1775, later known as protocadherin 21 (Pcdh21) (Nakajima et al., 2001). Using in situ hybridization, Nakajima and coworkers demonstrated how Pcdh21 is strongly expressed in both mitral and tufted cells of the OB and is moderately expressed in the piriform cortex and the septum in rats. 
TA B L E 1 Mitral and tufted cell-specific markers

\begin{tabular}{|c|c|c|c|c|c|}
\hline Marker & Specificity & Location & Methodology & Species & References \\
\hline $\begin{array}{l}\text { GLP-1 receptor/ } \\
\text { Exendin4 }\end{array}$ & MC, scattered GC & MCL & $\begin{array}{l}\text { Immunohistochemistry using anti GLP-1R; } \\
\text { fluorescent exendin4 (Ref AS-63714; } \\
\text { AnaSpec) }\end{array}$ & Mouse & Thiebaud et al. (2016) \\
\hline \multirow[t]{3}{*}{ Pcdh 21} & \multirow[t]{3}{*}{$\mathrm{MC}, \mathrm{TC}$} & \multirow[t]{3}{*}{ EPL, MCL } & In situ hybridization & Rat & Nakajima et al. (2001) \\
\hline & & & Transgenic mouse line: Pcdh21-Cre & Mouse & Nagai et al. (2005) \\
\hline & & & $\begin{array}{l}\text { Transgenic mouse line: Pcdh21-Cre from } \\
\text { (Nagai et al., 2005) }\end{array}$ & Mouse & Huang et al. (2013) \\
\hline \multirow[t]{2}{*}{ Tbr2 } & $\mathrm{MC}, \mathrm{GC}$ & MCL, GCL & In situ hybridization & Mouse & $\begin{array}{l}\text { Kimura, Nakashima, } \\
\text { Ueno, Kiyama, and } \\
\text { Taga (1999) }\end{array}$ \\
\hline & $\mathrm{MC}, \mathrm{TC}$ & EPL, MCL & $\begin{array}{l}\text { Conditional ablation; staining: anti Tbr2 } \\
\text { rabbit (from R.F Hevner) }\end{array}$ & Mouse & Kahoud et al. (2014) \\
\hline \multirow[t]{2}{*}{$\operatorname{Tbx} 21$} & & MCL & $\begin{array}{l}\text { Staining: guinea pig anti-Tbx21, custom } \\
\text { made }\end{array}$ & Mouse & Yoshihara (2005) \\
\hline & & EPL, MCL & $\begin{array}{l}\text { Immunohistochemistry using anti-T-bet/ } \\
\text { TBX21 (clone 4B10, 14-5825, } \\
\text { eBioscience) }\end{array}$ & Mouse & Yang et al. (2013) \\
\hline \multirow[t]{2}{*}{ Tbx21, Tbr1, Tbr2 } & MC & MCL & In situ hybridization & Mouse & Faedo et al. (2002) \\
\hline & $\mathrm{MC}, \mathrm{TC}$ & EPL, MCL & $\begin{array}{l}\text { In situ hybridization; transgenic mouse } \\
\text { lines }\end{array}$ & Mouse & $\begin{array}{l}\text { Mihalas and Hevner } \\
\text { (2017) }\end{array}$ \\
\hline $\begin{array}{l}\text { Tbx21, Tbr1, } \\
\text { Tbr2, Pcdh21 }\end{array}$ & & & $\begin{array}{l}\text { Immunohistochemistry using guinea pig } \\
\text { anti-Tbx21 from (Yoshihara, 2005); } \\
\text { rabbit anti Tbr1 (Abcam); rat } \\
\text { phycoerythrin-conjugated anti-Tbr2 } \\
\text { (1:200, eBioscience), rabbit anti-Pcdh21 } \\
\text { (1:1000) from (Yoshihara, 2005) }\end{array}$ & Mouse & Mitsui et al. (2011) \\
\hline
\end{tabular}

${ }^{a}$ GLP1-R is also present in neuronal populations within the cortex, hippocampus, amygdala and hypothalamus (Merchenthaler, et al., 1999; Cork et al., 2015).

These results have been confirmed in later studies using a transgenic mouse line, Pcdh21-Cre, in which the 10-kb mouse Pcdh 21 promoter drives the expression of Cre recombinase (Huang, Garcia, Jen, \& Arenkiel, 2013; Nagai, Sano, \& Yokoi, 2005; Storace \& Cohen, 2017) (Table 1). An interesting comparison of the T-box family markers and Pcdh21 was made by Mitsui and colleagues using triple immunofluorescence labelling in adult mice OB sections
(Mitsui et al., 2011). Their results show that Tbx21 is expressed in almost all MCs $(94.6 \% \pm 0.6 \%$ of Tbr- 1 positive MCs) and by a large population of TCs $(72.4 \% \pm 3.4 \%$ of Pcdh21-positive TCs).

Glucagon-like peptide 1 (GLP-1) and its precursor prepro-glucagon (PPG) are hormones secreted by intestinal enteroendocrine $\mathrm{L}$ cells upon food consumption. In addition to being gut-derived, GLP-1 is also synthesized in the brain by 
PPG-expressing neurons, located exclusively in the $\mathrm{OB}$ and in the caudal region of the nucleus of the solitary tract (Larsen, 1997; Merchenthaler, Lane, \& Shughrue, 1999; Vrang \& Larsen, 2010). Merchenthaler et al. (1999) were the first to describe PPG-positive cells in the glomerular layer of the OB. They assumed, because of their size and location, that these cells were either superficial short axon cells, or external tufted cells (ETCs). In the same study, GLP-1 receptor (GLP-1R) mRNA was abundantly present in the perykarya of MCs. This result was confirmed by more recent work, where GLP-1R was used as a marker of MCs (Cork et al., 2015; Thiebaud et al., 2016). PPGpositive cells instead, are thought to be mainly short axon cells (Cajal's cell) as they are mainly located in the granule cell layer (Thiebaud et al., 2016). While the synthesis of GLP-1 is limited to the $\mathrm{OB}$ and to the nucleus of the solitary tracts, GLP-1 receptors are widespread in the brain. GLP-1R-positive cells have been reported for example in the cortex, hippocampus, amygdala and in large numbers in the regions associated with autonomic and behavioural control of energy balance, such as the hypothalamus (Cork et al., 2015; Merchenthaler et al., 1999).

Physiologically, the presence of GLP-1R- and GLP-1producing cells in the $\mathrm{OB}$ demonstrates the ability of this organ to perform metabolic sensing (Fadool, Tucker, \& Pedarzani, 2011). More precisely the firing frequency of MCs is increased by GLP-1, enabling them to modulate olfactory detection in an energy state-dependent manner (Thiebaud et al., 2016). Thus, depending on the metabolic state of the body, the sensitivity and selectivity towards certain odourants is modified, most probably driving changes in food-seeking and food intake behaviours (Pager, Giachetti, Holley, \& Le Magnen, 1972).

To sum up, different molecular markers have been reported in literature to distinguish MCs and TCs from the rest of the cells in the OB. In this review we focus on GLP-1R, exclusively expressed in MCs, because it is found on the membrane and thus, may constitute a powerful tool for specifically targeting the MC population, which is impacted in the early stage of Parkinson's disease. Furthermore, GLP-1R agonists are currently widely use in the treatment of type II diabetes, are commercially available and, more importantly, are already FDA-approved. For a more complete understanding of mitral, tufted cells, their subgroups and their integration in the OB neural circuitry, the authors recommend the review from Nagayama, Homma, and Imamura (2014).

\section{2 | OB AND MC PATHOLOGY IN PD}

Disturbances of the olfactory system have been associated with PD for more than 40 years (Ansari \& Johnson, 1975) and the connection between PD and OB dysfunction is precisely at the point at which to speculate whether "PD is a primary olfactory disorder"(Hawkes, 1999). However, OB abnormalities are also a hallmark of other neurodegenerative diseases such as Alzheimer's disease (AD) (Devanand et al., 2000; Mundiñano et al., 2011; Serby, Larson, \& Kalkstein, 1991; Wang et al., 2010; Zou, Lu, Liu, Zhang, \& Zhou, 2016), Huntington's disease (Bacon Moore, Paulsen, \& Murphy, 1999; Barrios et al., 2007; Menalled, Sison, Dragatsis, Zeitlin, \& Chesselet, 2003), multiple sclerosis (Doty, Li, Mannon, \& Yousem, 1999; Silva et al., 2012; Zivadinov, Zorzon, Monti Bragadin, Pagliaro, \& Cazzato, 1999; Zorzon et al., 2000) and other synucleinopathies (Attems, Walker, \& Jellinger, 2014; Doty, 2012a), emphasizing a common, but still unclear, pathological background linking neurodegeneration and olfaction. Interestingly, among many of the disorders mentioned, OB disorders appear early in the progression of disease and thus, are being increasingly studied by the research community for the development of biomarkers or disease-modifying treatments.

In PD, hyposmia is considered to appear decades before the onset of motor symptoms and is present in nearly $90 \%$ of sporadic PD patients (Doty, 2012b; Doty, Deems, $\&, 1988)$, a prevalence higher than that of the main cardinal symptom of PD: tremor at rest ( 75\%) (Alves, Forsaa, Pedersen, Dreetz Gjerstad, \& Larsen, 2008). As one of the most salient nonmotor symptoms of $\mathrm{PD}$, olfactory dysfunction is now widely studied in the clinic using smell tests (e.g., UPSIT) (Doty, Shaman, \& Dann, 1984). This sensory dysfunction is accompanied, at a cellular level, by PD pathology. These findings were first reported in 1992 by Daniel and Hawkes (Daniel \& Hawkes, 1992), but scientific consensus was not reached until the comprehensive studies of Braak and coworkers, and culminated with the Braak stages theory of the progression of PD (Braak, Ghebremedhin, Rüb, Bratzke, \& Del Tredici, 2004; Braak, Del Tredici, et al., 2003; Hawkes, Del Tredici, \& Braak, 2010). The OB is involved from the preclinical stage I, with Lewy bodies (LBs) and Lewy neurites (LNs) present in olfactory structures (Braak, Rüb, Gai, \& Del Tredici, 2003; Braak et al., 2002). Not only synucleinopathy, but neuronal loss was also reported in the OB, especially in the mitral and tufted cells and in cells expressing calcium-binding proteins (Cave, Fujiwara, Weibman, \& Baker, 2016). Particularly affected is the AON, which in humans is partially located in the OB (Duda, 2010), where MCs form synapses with secondary afferent neurons. A close correlation between AON neuronal counts and disease duration was found in PD patients (Pearce, Hawkes, \& Daniel, 1995).

Mitral cells appear to be the neurons most affected in the olfactory bulb. They fall into the category of a vulnerable neuronal population, postulated by Braak et al. (2004); indeed they possess long, highly branched, poorly myelinated axons, projecting from the $\mathrm{OB}$ to the olfactory 
cortex. The lack of myelin makes the propagation of neuronal signals along the fibres very inefficient and the highly ramified morphology further increases the energy needs of these cells. It is estimated that nonmyelinated axons require an increase in approximately 5,000-fold in energy expenditure, over that of myelinated neurons, to maintain equivalent levels of neurotransmission (Bartzokis et al. 2003; Hildebrand, Remahl, Persson, \& Bjartmar, 1993). As between $2 \%$ and 3\% of physiological mitochondrial respiration is transformed into free radicals, the exorbitant increase in energy production results in a potentially toxic increase in reactive oxygen species (ROS) in the cell, making mitral cells a vulnerable target of oxidative stress. The same logic can be applied to the dopaminergic neurons of the substantia nigra, which, like mitral cells, possess long unmyelinated axons. In other neurons, a thick myelin sheath is stabilizing, preventing pathological axonal sprouting (Braak \& Del Tredici, 2004) and it has been speculated that myelin can act as a physical barrier blocking the cell-to-cell spreading of alpha-synuclein (Braak, Rüb, et al., 2003). In addition, mitral cells have been shown to be a potential target of nitration during ageing and are more affected by nitrosative stress than the other neurons in the OB (Yang et al., 2013). Reactive nitrogen species are not only a powerful source of free radicals, but also have the ability to promote alpha-synuclein aggregation through the nitration of tyrosine residues. Moreover, the presence of 3 -nytrotyrosine in lipofuscin granules in mitral and tufted cells has been reported (Yang et al., 2013). Interestingly, single LBs or a group of them, are typically located in close proximity to deposits of lipofuscin or neuromelanin (Braak, Del Tredici, et al., 2003) and are often reported to have increased 3-nytrotyrosine immunostaining (Duda et al., 2000; Good, Hsu, Werner, Perl, \& Warren Olanow, 1998). Lipofuscin granules are rich in metals, mainly copper and iron, that have also been shown to boost alphasynuclein aggregation (Brown, 2009; Carboni \& Lingor, 2015; Paik, Shin, Lee, Chang, \& Kim, 1999) and increase oxidative stress (Höhn, Jung, Grimm, \& Grune, 2010). The elevated nitration and oxidation typical of MCs may render them prone to develop LBs, that require a combination of particular conditions to occur, while LNs are seen also in other cell types in the OB like granule cells or substance P-positive neurons (Cave et al., 2016; Ubeda-Bañon, SaizSanchez, De La Rosa-Prieto, Argandoña-Palacios, et al., 2010).

Noteworthy is that the dopaminergic interneurons in the OB rarely express alpha-synuclein and are spared as PD progresses (Sengoku et al., 2008; Ubeda-Bañon, Saiz-Sanchez, de La Rosa-Prieto, Mohedano-Moriano, et al., 2010). More intriguingly, different studies have reported an increase as high as $100 \%$ in the intrabulbar dopaminergic population (Huisman, Uylings, \& Hoogland, 2004) that is particularly pronounced in females (Huisman, Uylings, \& Hoogland, 2008). Therefore, in contrast to what occurs in the substantia nigra, in the OB short-axon dopaminergic neurons are not degenerating but, on the contrary, may increase in number.

Another risk factor for mitral cells arises because of their direct synapses with the OSNs in the glomeruli. The olfactory epithelium and the OSNs are very rich in alpha-synuclein, where the protein is thought to have an antimicrobial function and an important role in the life-cycle of OSNs (Duda, Shah, Arnold, Lee, \& Trojanowski, 1999; Tomlinson et al., 2017). The protein can spread into mitral cells via synaptic junctions in the glomeruli (Figure 1). The aforementioned conditions in these cells may promote aberrant protein aggregation, while the OSNs are spared. Moreover, the high turnover of OSNs, cells with a 60-day lifespan, contributes to the difficulties of detecting any chronic pathology in such short-life neurons.

In conclusion, the increased oxidative and nitrative stress associated with the high metabolic demand, together with the abundance of lipofuscin, metals and alpha-synuclein, renders MCs particularly vulnerable in PD. They are affected at a very early stage and thus are an appealing target for diseasemodifying therapies that could block prion-like propagation of LB pathology to other areas of the brain.

\section{1 | Prion-like spreading}

In 2008, two papers published in Nature Medicine showed the presence of LBs in foetal grafted neurons in PDs patients, suggesting a spreading of alpha-synuclein pathology from the effected host to healthy grafted neurons (Kordower, Chu, Hauser, Freeman, \& Olanow, 2008; Li et al., 2008). It was the dawn of the prion-like principle for $\mathrm{PD}$ and $\mathrm{AD}$, a concept that after 10 years, is still not completely understood nor fully supported by the scientific community.

In $\mathrm{PD}$, the hypothesis is that a pathological insult, the nature of which is still unknown, triggers the misfolding of alpha-synuclein that then seeds aggregation of natively unfolded alpha-synuclein. The aberrant protein then spreads via neuronal connections, from the periphery to the centre (George, Rey, Reichenbach, Steiner, \& Brundin, 2013; Olanow \& Prusiner, 2009). It has been hypothesized that the activating insult could be a viral agent (Elizan \& Casals, 1983; Hawkes, Del Tredici, \& Braak, 2007) or exposure to environmental toxins, like pesticides, metals or other pollutants (Baltazar et al., 2014; Chin-Chan, Navarro-Yepes, \& Quintanilla-Vega, 2015; Levesque, Surace, McDonald, \& Block, 2011; Rey, Wesson, \& Brundin, 2018).

Although regarded by some as controversial and possibly over-stated (Steiner, Quansah, \& Brundin, 2018), many reports, some of which are listed below, are in line with the prion hypothesis, suggesting that PD starts in the olfactory bulb and in the Meissner's plexus (MP) of the enteric nervous system, and slowly progresses to affect other areas of the body and 
the brain, in a predictable and quite consistent pattern (George et al., 2013; Mason et al., 2016; Rey, Petit, Bousset, Melki, \& Brundin, 2013; Rey et al., 2016; Rey, George, et al., 2018). A "dual-hit" theory, proposed by Hawkes et al. (2007), Hawkes, Del Tredici, and Braak (2009) and more recently hypothesized to be the basis of a possible viraemic spread of certain neurotropic viruses (Mori, 2017), envisages the OB and MP as the interface between the CNS and a potentially hostile environment, such that these structures are considered critical to PD pathogenesis. The olfactory bulb is indeed a "window to the brain", where the neurons are not protected by the blood-brain barrier (BBB) (Perry, Mackay-Sim, Feron, \& McGrath, 2002) or by a thick myelin sheath and are in close proximity to possible insults. In particular, the OSNs are constantly exposed to noxious physical, chemical, and microbiological agents and thereby are regenerated and replenished throughout adulthood. The abundance of alpha-synuclein, that plays an important antimicrobial function at this interface (Park et al., 2016; Tomlinson et al., 2017), can be a fertile ground for the seeding of misfolded protein and the subsequent prion-like propagation after a triggering event. Interestingly, when this interface is compromised or inflamed, for example, in people suffering from allergic rhinitis, the risk of developing PD is increased (Bower, Maraganore, Peterson, Ahlskog, \& Rocca, 2006).

From the OB, the pathology may spread to the rest of the brain, following anatomically connected nerve pathways (Mason et al., 2016; Rey et al., 2013, 2016; Rey, George, et al., 2018; Ubeda-Bañon, Saiz-Sanchez, De La Rosa-Prieto, \& Martinez-Marcos, 2012, 2014). During Braak stage II, inclusions reach the locus coerulus, an area highly connected to the OB (Kebschull et al., 2016). At a later stage, secondary olfactory regions are involved, including the piriform cortex and the cortical amygdala, all areas innervated by MCs (Braak, Del Tredici, et al., 2003; Braak et al., 2004; Igarashi et al., 2012). The pathology spreads deeply into olfactory cortices, principally the peri-amygdaloid, and entorhinal cortices, but sparing the nonolfactory regions nearby (Braak, Del Tredici, et al., 2003; Hawkes et al., 2009; Ubeda-Bañon et al., 2014). The absence of mitral and tufted cell projections in these areas, and the reduced risk of aggregated alphasynuclein propagation can account for nonolfactory regions being relieved of the pathology.

A similar pattern of disease progression was reported in three in vivo studies in which alpha-synuclein fibrils where inoculated in the mouse OB (Mason et al., 2016; Rey et al., 2013, 2016). After three months, fibrils were reported in the piriform and entorhinal cortices, amygdala and some areas of the hippocampus (Mason et al., 2016). Rey and colleagues described a rapid uptake of fibrils by MCs, and the subsequent prion-like progression in projecting areas as early as one month after injection (Rey et al., 2016). Interestingly, no cell loss was detected for MCs, and when no uptake of larger fibrils was detected in these cells, no progression in other brain region was reported (Rey et al., 2016). As the regions affected receive direct projections from MCs, but also send axonal projections to MCs, fibril-axonal transport could occur in either anterograde and retrograde direction, as already proven in vitro (Freundt et al., 2012).

From olfactory cortices the pathology advances into other brain regions, affecting the substantia nigra at Braak stage III. This region is under a "crossfire" receiving inputs (and most likely misfolded alpha-synuclein) not only from secondary olfactory regions, but also from the brainstem. Aggregated alpha-synuclein could, in fact, reach the CNS via peripheral nerves from the Meissner's plexus (Hawkes et al., 2009). At this point, when the nigral dopaminergic population is compromised, the motor symptoms arise. In the later stages, PD pathology progresses further, slowly affecting other cortical regions and also hippocampal formations, while the cognitive and motor symptoms intensify and worsen (Hawkes et al., 2010; Kalia \& Lang, 2015).

\section{MITRAL CELL GLP-1R AS A THERAPEUTIC TARGET IN PD}

Prodromal PD is an ideal stage at which neuroprotective and disease-modifying therapies could be applied. Preventing the spread of aggregated alpha-synuclein from vulnerable anatomical sites during this phase could slow the disease process and even prevent the occurrence of motor symptoms during the lifetime of a patient (Brundin, Dave, \& Kordower, 2017). As MCs could be involved in the progression and spreading of synuclein pathology from a very early stage, we propose that specific targeting of this cell population in the $\mathrm{OB}$ could halt, or at least retard, the progression of PD (Braak, Del Tredici, et al., 2003; Cave et al., 2016; Daniel \& Hawkes, 1992; Rey et al., 2016; Ubeda-Bañon, Saiz-Sanchez, De La Rosa-Prieto, Argandoña-Palacios, et al., 2010; Ubeda-Bañon, Saiz-Sanchez, de La Rosa-Prieto, Mohedano-Moriano, et al., 2010; Ubeda-Bañon et al., 2014). GLP-1R, located on the cell membrane, could be a suitable candidate protein for specific targeting of MCs. Furthermore, the activation of GLP-1R, using GLP-1 or analogues of GLP-1, has already shown great potential and beneficial effects in preclinical studies for the treatment of neurodegenerative diseases, as summarized in Table 2

GLP-1 is an endogenous 30-amino acid long peptide hormone secreted from small intestine $\mathrm{L}$ cells in response to food ingestion. It acts as an incretin hormone, stimulating glucoseinduced insulin secretion and biosynthesis and inhibiting glucagon secretion, thus mediating glucose homeostasis (Holst, 2007). In the human body, GLP-1 is rapidly inactivated by the circulating enzyme dipeptidyl peptidase IV (DPP-IV) in metabolites not active against the GLP-1R, making its pharmacological use impractical (Drucker, 2003; Kieffer, McIntosh, 
TA B L E 2 Effects of GLP-1 analogues in relevant experimental models

\begin{tabular}{|c|c|c|c|c|}
\hline Effect & Drug & Results & Model/cell type & References \\
\hline
\end{tabular}

Exendin-4, Increased neuroprotection of liraglutide and Liraglutide, Lixisenatide

Geniposide

GLP-1, Exendin-4

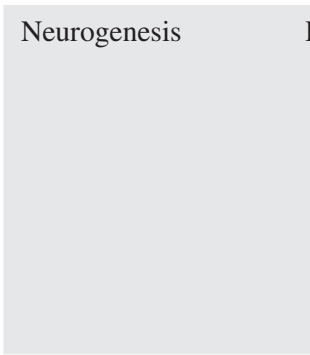

Neuroinflammation

Exendin-4

GLP-1

\begin{tabular}{|c|c|c|}
\hline \multirow[t]{2}{*}{ Neurotrophic factors } & Exendin-4 & $\begin{array}{l}\text { Increased number of neurites; increased } \\
\text { conductance of } \mathrm{Na}^{+} \text {channels and amplitude of } \\
\mathrm{Ca}^{2+} \text { currents } \\
\text { Increased production of BDNF, increased } \\
\text { membrane trafficking and cleavage of APP } \\
\text { preventing amyloid- } \beta \text { formation }\end{array}$ \\
\hline & $\begin{array}{l}\text { GLP-1, Exendin-4, } \\
\text { Exendin-4-WOT }\end{array}$ & $\begin{array}{l}\text { Induced neurite outgrowth; promoted NGF- } \\
\text { initiated differentiation; rescued degenerating } \\
\text { cells after NGF-withdrawal }\end{array}$ \\
\hline \multirow[t]{3}{*}{ Oxidative stress } & Exendin-4 & $\begin{array}{l}\text { Increased viability of PC12 cells and ameliorated } \\
\text { oxidative stress-induced cell death; improved } \\
\text { learning and memory performance and rescued } \\
\text { hippocampal neurons in vivo }\end{array}$ \\
\hline & Geniposide & $\begin{array}{l}\text { Increased expression of anti-apoptotic proteins; } \\
\text { prevented oxidative damage }\end{array}$ \\
\hline & GLP-1 & $\begin{array}{l}\text { Protection from oxidative stress-induced } \\
\text { apoptosis; Induced redox restoration }\end{array}$ \\
\hline
\end{tabular}

lixisenatide compared to exendin-4; reduced expression of the pro-apoptotic molecule BAX and increased in the anti-apoptotic signalling molecule Bcl-2.

Motor improvements; restored TH neurons; reduced apoptosis signalling molecule BAX and caspase 3 activation; increased expression of anti-apoptotic protein $\mathrm{Bcl}-2$

Increased mitochondrial mass, oxygen consumption, membrane potential and mitochondria/ cytosol ratio

Increased hippocampal neurogenesis; improved cognitive performances

Increased number of neural progenitor cells in vitro; increased neurogenesis in vitro; normalized dopamine imbalance and increased number of dopaminergic cell in PD model

Increased cell proliferation and neuroblast differentiation in the SGZ of the dentate gyrus

Reversed loss of extracellular dopamine; attenuated loss of TH neurons

Suppressed expression of pro-inflammatory cytokines; prevented microglia activation; attenuated loss of dopaminergic fibres

Prevented depressive-like behaviour without affecting pro-inflammatory cytokines

Prevented LPS-induced IL-1 $\beta$ mRNA expression apoptosis; Induced redox restoration
MPTP PD mouse model Liu et al. (2015)

MPTP PD mouse model Chen et al.

INS-1 rat insulinoma Kang et al. cells

Adult rat and mouse

Isacson et al.

Neural stem cells;

Bertilsson et al.

6-OHDA model of PD (2008)

Adult mouse

Li et al. (2010)

6-OHDA and LPS PD

Harkavyi et al.

mouse models

(2008)

MPTP PD mouse model

Kim et al.

(2009)

LPS rat model, without

Ventorp et al. degeneration

Primary astrocyte

Iwai et al. culture, LPS treated

SH-SY5Y cells

Luciani et al. (2010)

Amyloid- $\beta$ treated

Ohtake et al. mouse (2014)

PC12 cells Perry, Lahiri, et al. (2002)

PC12 cells; diabetes-

Chen et al. related $\mathrm{AD}$ rat model

(2012)

Hydrogen peroxide-

Liu et al. (2007) treated PC12 cells

Methylglyoxal-treated

Kimura et al. PC12 cells 
TA B L E 2 (Continued)

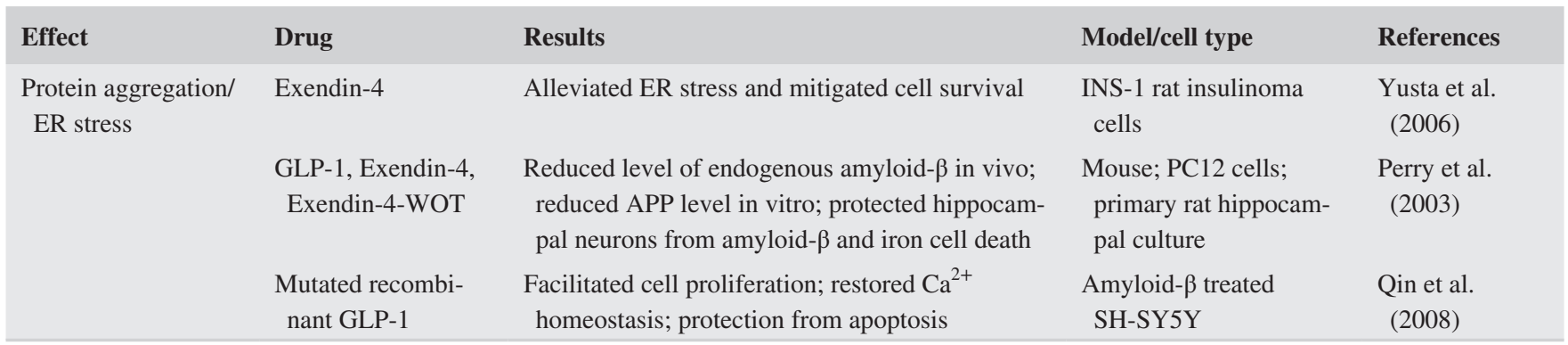

$\&$ Pederson, 1995). However, a natural GLP-1 agonist, resistant to DPP-IV enzymatic degradation was discovered in the saliva of the Gila monster (Heloderma suspectum), a venomous lizard native to the south-western desert of the American plains (Eng, Kleinman, Singh, Singh, \& Raufman, 1992). This 39-amino acid peptide, named exendin-4, and its several synthetic versions, exenatide for example, have enabled the therapeutic use of GLP-1 agonists, overcoming the short biological half-life of GLP-1 (Parkes, Mace, \& Trautmann, 2013). At present, exenatide is widely used for the treatment of type 2 diabetes, but it has also been tested recently in postdromal PD patients in clinical trials (Athauda et al., 2017; Aviles-Olmos et al., 2013). An increasing number of findings suggest that exenatide and other GLP-1R agonists are able to cross the $\mathrm{BBB}$, and influence various cellular pathways related, for example, to neurogenesis, cellular proliferation, neuroinflammation and mitochondrial function in the CNS. Below and in Table 2, we summarize the most relevant findings about GLP-1 analogues and their neuroprotective role, with a particular focus on their potential to alleviate $\mathrm{OB}$ and $\mathrm{MC}$ pathology in $\mathrm{PD}$.

Neuroinflammation, due to a chronic microglial activation, is considered a pivotal player in the pathogenesis of PD and is particularly prevalent in the $\mathrm{OB}$. At this gateway to the environment, microglia are very abundant and in a constant alert-state (Lalancette-Hbert, Phaneuf, Soucy, Weng, \& Kriz, 2009; Lawson, Perry, Dri, \& Gordon, 1990). Indeed, microglia are able to sense an inflammatory response due to an injury occurring far from the $\mathrm{OB}$ and to become activated as a consequence (Lalancette-Hbert et al., 2009). The mitigation of a microglial response could ultimately decrease neuronal loss and slow disease progression. GLP-1 analogues have been shown to prevent cytotoxic microglial activation and to suppress production of pro-inflammatory cytokines, such as TNF- $\alpha$ and IL-1 $\beta$, in toxin models of PD (Harkavyi et al., 2008; Kim, Moon, \& Park, 2009; Spielman, Gibson, \& Klegeris, 2017) and in vitro LPS-treated astrocyte cultures (Iwai, Ito, Tanimitsu, Udagawa, \& Oka, 2006). In diabetic rats, exenatide and other GLP-1R agonists have demonstrated antipsychotic and antidepressant effects, thought to be due to an anti-inflammatory response (Rocha, Reis, Vanden Berghe, \& Cirillo, 2014; Sharma, Ligade, et al., 2015; Tarkun, 2014).
A similar antidepressant behaviour was reported for exendin-4 in a rat inflamed model, but without neurodegeneration (Ventorp et al., 2017). However, Ventorp and coworkers reported no change in pro-inflammatory cytokines in their model. The explanation could be that in the previously described studies the models used involved both inflammation and neurodegeneration, thus the decreased inflammation could have been secondary to a reduced neurodegeneration. The molecular pathway through which GLP-1 analogues modulate microglial response and mitigate inflammation, is not completely clear yet, but it might involve the nuclear factor kappa-light-chain-enhancer of activated B cells (NF$\kappa \mathrm{B})$, important in the inflammatory gene expression regulation and upregulated in the pathogenesis of PD (Athauda \& Foltynie, 2016).

GLP-1 and its analogues have shown promising results in preventing protein aggregation, a vulnerable factor for MCs. The upregulation of sirtuin 1 (SIRT1), a protein involved in the control of autophagy, has been demonstrated after GLP-1R activation in different disease models (Lee et al., 2014; Lennox et al., 2014). An alleviation of ER stress and an improvement in cell survival was reported in vitro after treatment with exendin-4 (Yusta et al., 2006). Similar results were described more recently by Lee and colleagues, and were attributed to an increased expression of SIRT1 (Lee et al., 2014). In PD models, SIRT1 upregulation has been shown to reduce alpha-synuclein aggregation and alphasynuclein-induced toxicity (Herskovits \& Guarente, 2014; Sampaio-Marques et al., 2012). Another potential therapeutic mechanism of action is through the activation of the insulindegrading enzyme (IDE). IDE has been proven to efficiently prevent the formation of alpha-synuclein fibrils by binding to oligomers and rendering them inert to the formation of aggregates (Sharma, Chorell, et al., 2015). Interestingly, geniposide, a GLP-1R agonist extracted from Gardenia fruit, has been shown to upregulate IDE expression, and thus, is thought able to prevent alpha-synuclein misfolding. Activation of GLP-1R resulted in neuroprotection also in $A D$ models, preventing the formation of toxic amyloid- $\beta$ and reducing levels of amyloid precursor protein (APP) (Perry et al., 2003; Qin et al., 2008). A reduction in tau hyperphosphorylation, a hallmark of $\mathrm{AD}$ but also present in numerous 
cases of Parkinson's, was reported in diabetic mice after exendin-4 treatment (Xu et al., 2015).

Particularly significant in the proposed context of targeting MCs, is the mitigation of mitochondrial dysfunction and the reduction in oxidative stress. As already mentioned, the high number of dendritic branches and the long-range projections that demand a high rate of mitochondrial oxidative metabolism, render MCs particularly sensitive to oxidative and mitochondrial damage. In a PD toxin model, geniposide and two newer GLP-1 analogues, lixisenatide and liraglutide, have produced beneficial effects on mitochondria, rescuing dopaminergic neurons through the increased expression of anti-apoptosis protein B-cell lymphoma 2 (Bcl-2) and the suppression of the pro-apoptotic signalling molecule Bcl-2associated X protein (BAX) (Chen, Zhang, Li, \& Hölscher, 2015; Liu et al., 2015). These results agree with the reported preservation of mitochondrial membrane potential and a subsequent reduction in cytochrome $\mathrm{c}$ release in exendin-4treated animals after spinal cord injury (Li et al., 2015). An increase in either the mitochondrial membrane potential and the mitochondrial mass was also reported in vitro after GLP-1 treatment, an indication of enhanced mitochondrial performances and biogenesis (Kang, Oh, \& Cho, 2015). Exendin-4 treatment also reduced oxidative stress-induced injury in cultured PC12 cells and attenuated hippocampal neurodegeneration in an in vivo AD model through the activation of the phosphatidylinositide 3-kinases (PI3K) pathway (Chen, Liu, An, Yao, \& Gao, 2012; Kimura et al., 2009; Liu, Yin, Zheng, Jing, \& Hu, 2007).

Intriguingly, another mechanism of action of GLP-1 analogues could be through the inhibition of the potassium channel Kv1.3 through the activation of protein kinase A (PKA) (Chung \& Schlichter, 1997; Kovach et al., 2016; Thiebaud et al., 2016). This channel is highly expressed by MCs, where it controls $60 \%-80 \%$ of outward potassium currents (Fadool \& Levitan, 1998; Fadool et al., 2004) and it is overexpressed in microglia upon inflammation (Fordyce, Jagasia, Zhu, \& Schlichter, 2005) and in AD patients (Rangaraju, Gearing, Jin, \& Levey, 2015). The inhibition of Kv1.3 has shown beneficial effects that mitigate inflammation (Fordyce et al., 2005; Koeberle \& Schlichter, 2010; Thomas et al., 2007), improve mitochondrial functions and resistance (Kovach et al., 2016) and inhibit apoptosis through the prevention of BAX-induced cytochrome c release (Gulbins, Sassi, Grassmè, Zoratti, \& Szabò, 2010; Szabó et al., 2008).

GLP-1R activation can also influence the expression of trophic factors in the CNS, bypassing their main limitation: the poor ability to cross the BBB after systemic administration. In particular, the expression of brain-derived neurotrophic factor (BDNF), widely used in PD research to promote neuronal survival and regeneration, was shown to be upregulated and to exert a neuroprotective effect in an AD mouse model after an intraperitoneal injection of exendin-4 (Ohtake, Saito,
Eto, \& Seki, 2014). A more recent study has described an increase in neurotrophic factor expression in GLP-1-treated glial cells, resulting in a mitigation of TNF- $\alpha$-induced oxidative stress and an improved cell survival (Spielman et al., 2017) GLP-1 analogues themselves could directly function as trophic factors. Indeed, in vitro studies demonstrated that exendin-4 treatment induced neurite outgrowth, resembling the effects of nerve growth factor (NGF); GLP-1 was also able to rescue neurons in NGF-mediated withdrawal experiments, underlying two independent trophic effects (Luciani et al., 2010; Perry, Haughey, Mattson, Egan, \& Greig, 2002; Perry, Lahiri, et al., 2002). In addition, exendin-4 increased electrophysiological performances of SH-SY5Y cells, a sign of a more mature neuronal phenotype (Luciani et al., 2010).

Another possible therapeutic effect of the GLP-1R could be due to a reported ability to promote neurogenesis. In the human brain, neurogenesis occurs in restricted areas during adulthood, including the SVZ and, to a lesser (and still debatable) extent in the OB (Macklis, 2012; Maheu et al., 2015). The levels of neurogenesis decline with age and are decreased in neurodegenerative disorders like PD. Physiologically, a portion of new-born neurons migrate through the RMS into the $\mathrm{OB}$ and integrate in the neural circuitry, mainly replacing granule cells and interneurons. Therefore, a boost in the neurogenesis capacity of SVZ and OB could prevent some olfactory dysfunction typical of prodromal PD. GLP-1R activation has been linked to an increased number of neuronal progenitor cells in the SVZ and in the hippocampal subgranular zone (SGZ) in vivo; it has also been shown to promote cell differentiation towards a more mature neuronal phenotype (Bertilsson et al., 2008; Isacson et al., 2011; Li et al., 2010; Luciani et al., 2010; Salcedo, Tweedie, Li, \& Greig, 2012).

The above beneficial effects of GLP-1 analogue treatment (summarized in Table 2), result from the synergistic action of different molecular pathways. First, GLP-1R activation leads to an upregulation of PI3K and consequently protein kinase B (AKT), which acts as a regulator of physiological responses to ageing. AKT has the ability to inhibit several substrate proteins, including NF- $\mathrm{\kappa B}$, Forkhead box protein O1 (FOXO1), glycogen synthase kinase 3 beta (GSK3B) and mammalian target of rapamycin (mTOR), ultimately reducing pro-apoptotic signalling, inhibiting pro-inflammatory cytokine release and preventing oxidative stress. Other effects may be PKA-mediated. For example, a downstream target of PKA activity is the mitogen-associated protein kinase/ extracellular signal-regulated kinase (MAPK/ERK) pathway, which promotes neuronal survival, proliferation, and differentiation and inhibits the inflammatory cascade. The increase in intracellular cAMP activates the cAMP response element-binding protein (CREB). CREB-mediated signalling increases production of BDNF, but also decreases the expression of pro-apoptotic molecules (Athauda \& Foltynie, 2016, 2017; Kimura et al., 2009; Liu et al., 2007). 


\section{1 | Following our noses: intranasal delivery of MC-targeting therapeutics}

Less than two percent of drugs developed for the treatment of brain-related disorders are reported to penetrate the BBB in a sufficient dose to exert a therapeutic effect (Miyake \& Bleier, 2015). Intranasal delivery (IND) to the brain can not only overcome this major barrier to the development of new drugs, but it may have additional benefits. For example, reduced side effects, when compared with systemic administration, and the avoidance of invasive CNS delivery using brain implants that can cause a foreign-body response. IND also exploits a readily accessible, large surface area of porous endothelial membrane that incorporates a high total blood flow. Moreover, local drug delivery to this brain-adjacent site can bypass, to some extent, the problem of hepatic degradation, and may reduce drug delivery to off-target sites, enabling a reduction in dose administration (Frey, 2002; Hanson \& Frey, 2008; Miyake \& Bleier, 2015).

We propose that during prodromal $\mathrm{PD}$, the activation of GLP-1R in MCs, could potentially halt or slow the spread of toxic pathology from olfactory structures to deeper areas of the brain.

Interestingly, using a rodent model, the rapid uptake into the brain of exendin-9, an antagonist of the GLP-1 family was described (Banks, 2004). After intranasal administration, exendin-9 was found in the hippocampus, cerebellum, brainstem, cerebrospinal fluid and particularly, in the olfactory bulb, confirming the utility of the nasal route to target this brain region. Excitingly, in a proof-of-concept human study, Born, Lange, and Kern (2002), were able to detect the presence of three neuropeptides in the cerebrospinal fluid after their intranasal administration. Several clinical trials have since investigated this technique for the treatment of various pathological conditions. For example, a recently concluded trial (ClinicalTrials.gov Identifier: NCT01398748) tested intranasal delivery of glutathione for the treatment of oxidative stress in $\mathrm{PD}$, while many more are exploring the use of transnasal delivery of GLP-1 analogues, mainly for the treatment of diabetes (see clinicaltrials.gov).

Despite these promising efforts, the application of IND in clinical models of human disease is not without its limitations. First, nasal epithelia in animals used in preclinical models differ greatly from those in humans, where for example, the olfactory epithelium occupies a very small portion of the nasal cavity (3\% in human, $50 \%$ in rodents) (Morrison \& Costanzo, 1992). This suggests that studies in rodents may overestimate the bioavailability of therapeutic agents after trans-nasal delivery. Furthermore, many studies use swallowprevention methodologies that could not be implemented in humans, such as high pressure, mucosa-damaging permeation enhancers or surgical procedures (Merkus, Guchelaar, Bosch, $\&$ Merkus, 2003; Miyake \& Bleier, 2015). Therefore, more translational criteria should be applied to the design of intranasal delivery systems used in preclinical studies, in order to validate this administration route for use in PD patients.

An intriguing approach that could overcome some of the above limitations, is nasal mucosal grafting. This technique can overcome the problem of dripping and swallowing of the therapeutic compound and the muco-ciliary drug clearance from the nose (Djupesland, Mahmoud, \& Messina, 2013; Merkus, Verhoef, Schipper, \& Marttin, 1998). Nasal mucosal grafting, for the delivery of GDNF, has proven to be as efficient as intrastriatal injection in a murine model of PD (Bleier et al., 2016), confirming a previous report that mucosal grafts are permeable to high molecular weight compounds, up to $500 \mathrm{kDa}$ (Bleier, Kohman, Feldman, Ramanlal, $\&$ Han, 2013). Perhaps further improvements of this technology could be made by exploiting innovative drug delivery systems that can allow for a sustained drug release, particularly relevant in the case of a chronic disease like PD. Biomaterials, such as chitosan, collagen or hyaluronic acid, can be used to create drug delivery devices with a tuneable rate of release (Khaing, Thomas, Geissler, \& Schmidt, 2014; Thomas et al., 2014). Recently, devices have been patented for ultra-long-term release of GLP-1 analogues for the treatment of type 2 diabetes, such as ITCA 650 or VRS-859. The ITCA 650, a mini pump the size of a matchstick, is able to release therapeutic exenatide for up to 12 months and has already proven efficacy and safety in different clinical trials (Henry et al., 2014, 2018; Mullard, 2014; Rosenstock et al., 2018). The development of a ITCA 650-inspired device for the intranasal delivery of GLP-1R agonist from a biomaterial scaffold could change the treatment of PD, allowing a more patient-friendly drug delivery platform.

\section{CONCLUDING REMARKS}

The olfactory bulb is negatively impacted by Parkinson's disease years before clinically manifested motor symptoms. In the $\mathrm{OB}, \mathrm{MCs}$ are particularly vulnerable to the stresses caused by PD. As the major projection neurons of the OB, MCs play a pivotal role in the propagation of misfolded alpha-synuclein, which is hypothesized by some researchers to travel along their axons before reaching deeper structures within the brain. For this reason, rescuing MCs could prevent the spread of aberrant protein, possibly retaining PD pathology within the OB. In this regard, appropriate in vitro and ex vivo models of prodromal OB PD pathology will be important tools in optimizing MC-targeting approaches and for testing novel therapeutics that could rescue MC pathology.

Amongst all the markers expressed by MCs, GLP-1R seems the most appropriate to exploit as part of an MC-specific targeting strategy. Not only is this receptor protein located on the cell surface, and thus more accessible than other known markers, but 
an added advantage is that GLP-1R activation has been shown to have many beneficial effects. Indeed, GLP-1 analogues were reported to mitigate the microglial response, known to be particularly harsh in the $\mathrm{OB}$; they may also alleviate oxidative stress and reduce pro-apoptotic signalling, a strategy that could rescue MCs. In addition, exendin-4 and other similar peptides could prevent the formation of alpha-synuclein aggregates and thus, could limit the prion-like spreading of misfolded alphasynuclein from MCs in the OB to other parts of the CNS.

The location of MCs within the OB makes intranasal delivery of GLP-1 analogues during pro-dromal disease, with a view to targeting MCs and possibly halting PD progression, a highly appealing and realistic prospect. Particularly attractive is the possibility of exploiting long-term release of therapeutic compounds using innovative drug delivery systems such as nasal grafting and/or micro-osmotic pumps, and biomaterialmediated drug release. The sweet smell of GLP-1R targeting may well prove to be a success in future PD treatment.

\section{ACKNOWLEDGEMENTS}

This work has been funded by the European Union Horizon 2020 Programme (H2020-MSCA-ITN-2015) under the Marie Sklodowska-Curie Innovative Training Networks and Grant Agreement No. 676408. Additionally, this publication has emanated from research supported in part by a research grant from Science Foundation Ireland (SFI) and is cofunded under the European Regional Development Fund under Grant Number 13/RC/2073. The authors thank Mr Maciej Doczyk and Dr Jill McMahon for their help with the graphic illustrations, and Mr. Anthony Sloan for his useful advice in the revision of the manuscript.

\section{CONFLICT OF INTERESTS}

The authors declare no conflict of interests.

\section{AUTHOR CONTRIBUTIONS}

E.B. completed the literature search and wrote the manuscript. E.B. and U.F. conceived of the overall idea for the review.

\section{ORCID}

Enrico Bagnoli (D) http://orcid.org/0000-0002-0664-9981

Una FitzGerald (D) http://orcid.org/0000-0002-8019-6546

\section{REFERENCES}

Alves, G., Forsaa, E. B., Pedersen, K. F., Dreetz Gjerstad, M., \& Larsen, J. P. (2008). Epidemiology of Parkinson's disease. Journal of Neurology, 255, 18-32. https://doi.org/10.1007/s00415-008-5004-3
Ansari, K. A., \& Johnson, A. (1975). Olfactory function in patients with Parkinson's disease. Journal of Chronic Disease, 28, 493-497. https://doi.org/10.1016/0021-9681(75)90058-2

Athauda, D., \& Foltynie, T. (2016). The glucagon-like peptide 1 (GLP) receptor as a therapeutic target in Parkinson's disease: Mechanisms of action. Drug Discovery Today, 21, 802-818. https://doi. org/10.1016/j.drudis.2016.01.013

Athauda, D., \& Foltynie, T. (2017). Protective effects of the GLP-1 mimetic exendin-4 in Parkinson's disease. Neuropharmacology, 136, 260-270.

Athauda, D., Maclagan, K., Skene, S. S., Bajwa-Joseph, M., Letchford, D., Chowdhury, K., ... Foltynie, T. (2017). Exenatide once weekly versus placebo in Parkinson's disease: A randomised, doubleblind, placebo-controlled trial. Lancet, 390, 1664-1675. https://doi. org/10.1016/S0140-6736(17)31585-4

Attems, J., Walker, L., \& Jellinger, K. A. (2014). Olfactory bulb involvement in neurodegenerative diseases. Acta Neuropathologica, 127, 459-475. https://doi.org/10.1007/s00401-014-1261-7

Aviles-Olmos, I., Dickson, J., Kefalopoulou, Z., Djamshidian, A., Ell, P., Soderlund, T., ... Foltynie, T. (2013). Exenatide and the treatment of patients with Parkinson's disease. Journal of Clinical Investigation, 123, 2730-2736. https://doi.org/10.1172/JCI68295

Bacon Moore, A., Paulsen, J. S., \& Murphy, C. (1999). A test of odor fluency in patients with Alzheimer's and Huntington's disease. Journal of Clinical and Experimental Neuropsychology, 21, 341351. https://doi.org/10.1076/jcen.21.3.341.918

Baltazar, M. T., Dinis-Oliveira, R. J., de Lourdes Bastos, M., Tsatsakis, A. M., Duarte, J. A., \& Carvalho, F. (2014). Pesticides exposure as etiological factors of Parkinson's disease and other neurodegenerative diseases-A mechanistic approach. Toxicology Letters, 230, 85-103. https://doi.org/10.1016/j.toxlet.2014.01.039

Banks, W. A. (2004). Brain uptake of the glucagon-like peptide-1 antagonist exendin(9-39) after intranasal administration. Journal of Pharmacology and Experimental Therapeutics, 309, 469-475. https://doi.org/10.1124/jpet.103.063222

Bargmann, C. I. (2006). Comparative chemosensation from receptors to ecology. Nature, 444, 295-301. https://doi.org/10.1038/nature05402

Barrios, F. A., Gonzalez, L., Favila, R., Alonso, M. E., Salgado, P. M., Diaz, R., \& Fernandez-Ruiz, J. (2007). Olfaction and neurodegeneration in HD. NeuroReport, 18, 73-76. https://doi.org/10.1097/ WNR.0b013e3280102302

Bartzokis, G., Cummings, J. L., Sultzer, D., Henderson, V. W., Nuechterlein, K. H., \& Mintz, J. (2003). White matter structural integrity in healthy aging adults and patients with Alzheimer disease. Archives of Neurology, 60, 393. https://doi.org/10.1001/ archneur.60.3.393

Bertilsson, G., Patrone, C., Zachrisson, O., Andersson, A., Dannaeus, K., Heidrich, J., ... Wikström, L. (2008). Peptide hormone exendin-4 stimulates subventricular zone neurogenesis in the adult rodent brain and induces recovery in an animal model of Parkinson's disease. Journal of Neuroscience Research, 86, 326-338. https://doi. org/10.1002/(ISSN)1097-4547

Bleier, B. S., Kohman, R. E., Feldman, R. E., Ramanlal, S., \& Han, X. (2013). Permeabilization of the blood-brain barrier via mucosal engrafting: Implications for drug delivery to the brain. PLOS ONE, 8, e61694. https://doi.org/10.1371/journal.pone.0061694

Bleier, B. S., Kohman, R. E., Guerra, K., Nocera, A. L., Ramanlal, S., Kocharyan, A. H., ... Han, X. (2016). Heterotopic mucosal grafting enables the delivery of therapeutic neuropeptides across the blood 
brain barrier. Neurosurgery, 78, 448-457. https://doi.org/10.1227/ NEU.0000000000001016

Born, J., Lange, T., \& Kern, W. (2002). Sniffing neuropeptides: A transnasal approach to the human brainNature Neuroscience, 5, 9-11.

Bower, J. H., Maraganore, D. M., Peterson, B. J., Ahlskog, J. E., \& Rocca, W. A. (2006). Immunologic diseases, anti-inflammatory drugs, and Parkinson disease: A case-control study. Neurology, 67, 494-496. https://doi.org/10.1212/01.wnl.0000227906.99570.cc

Braak, H., \& Del Tredici, K. (2004). Poor and protracted myelination as a contributory factor to neurodegenerative disorders. Neurobiology of Aging, 25, 19-23. https://doi.org/10.1016/j. neurobiolaging.2003.04.001

Braak, H., Del Tredici, K., Bratzke, H., Hamm-Clement, J., SandmannKeil, D., \& Rüb, U. (2002). Staging of the intracerebral inclusion body pathology associated with idiopathic Parkinson's disease (preclinical and clinical stages). Journal of Neurology, 249, 1-1. https:// doi.org/10.1007/s00415-002-1301-4

Braak, H., Del Tredici, K., Rüb, U., De Vos, R. A. I., Jansen Steur, E. N. H., \& Braak, E. (2003). Staging of brain pathology related to sporadic Parkinson's disease. Neurobiology of Aging, 24, 197-211. https://doi.org/10.1016/S0197-4580(02)00065-9

Braak, H., Ghebremedhin, E., Rüb, U., Bratzke, H., \& Del Tredici, K. (2004). Stages in the development of Parkinson's disease-related pathology. Cell and Tissue Research, 318, 121-134. https://doi. org/10.1007/s00441-004-0956-9

Braak, H., Rüb, U., Gai, W. P., \& Del Tredici, K. (2003). Idiopathic Parkinson's disease: Possible routes by which vulnerable neuronal types may be subject to neuroinvasion by an unknown pathogen. Journal of Neural Transmission, 110, 517-536. https://doi. org/10.1007/s00702-002-0808-2

Brill, M. S., Ninkovic, J., Winpenny, E., Hodge, R. D., Ozen, I., Yang, R., ... Götz, M. (2009). Adult generation of glutamatergic olfactory bulb interneurons. Nature Neuroscience, 12, 1524-1533. https://doi. org/10.1038/nn.2416

Brown, D. R. (2009). Metal binding to alpha-synuclein peptides and its contribution to toxicity. Biochemical and Biophysical Research Communications,380,377-381.https://doi.org/10.1016/j.bbrc.2009. 01.103

Brundin, P., Dave, K. D., \& Kordower, J. H. (2017). Therapeutic approaches to target alpha-synuclein pathology. Experimental Neurology, 298, 225-235. https://doi.org/10.1016/j.expneurol. 2017.10.003

Carboni, E., \& Lingor, P. (2015). Insights on the interaction of alphasynuclein and metals in the pathophysiology of Parkinson's disease. Metallomics, 7, 395-404. https://doi.org/10.1039/C4MT00339J

Cave, J. W., Fujiwara, N., Weibman, A. R., \& Baker, H. (2016), Cytoarchitectural changes in the olfactory bulb of Parkinson's disease patients. NPJ Parkinson's Disease, 2, 16011. https://doi. org/10.1038/npjparkd.2016.11

Chen, S., Liu, A. R., An, F. M., Yao, W. B., \& Gao, X. D. (2012). Amelioration of neurodegenerative changes in cellular and rat models of diabetes-related Alzheimer's disease by exendin-4. Age (Omaha), 34, 1211-1224. https://doi.org/10.1007/s11357-011-9303-8

Chen, Y., Zhang, Y., Li, L., \& Hölscher, C. (2015). Neuroprotective effects of geniposide in the MPTP mouse model of Parkinson's disease. European Journal of Pharmacology, 768, 21-27. https://doi. org/10.1016/j.ejphar.2015.09.029

Chin-Chan, M., Navarro-Yepes, J., \& Quintanilla-Vega, B. (2015). Environmental pollutants as risk factors for neurodegenerative disorders: Alzheimer and Parkinson diseases. Frontiers in Cellular Neuroscience, 9, 1-22.

Chung, I., \& Schlichter, L. C. (1997). Regulation of native Kv1.3 channels by cAMP-dependent protein phosphorylation. American Journal of Physiology, 273, C622-C633. https://doi.org/10.1152/ ajpcell.1997.273.2.C622

Cork, S. C., Richards, J. E., Holt, M. K., Gribble, F. M., Reimann, F., \& Trapp, S. (2015). Distribution and characterisation of Glucagon-like peptide-1 receptor expressing cells in the mouse brain. Molecular Metabolism, 4, 718-731. https://doi.org/10.1016/j.molmet.2015.07.008

Daniel, S., \& Hawkes, C. (1992). Preliminary diagnosis of Parkinson's disease by olfactory bulb pathology. Lancet, 340, 186. https://doi. org/10.1016/0140-6736(92)93275-R

Devanand, D. P., Michaels-Marston, K. S., Liu, X., Pelton, G. H., Padilla, M., Marder, K., ... Mayeux, R. (2000). Olfactory deficits in patients with mild cognitive impairment predict Alzheimer's disease at follow-up. American Journal of Psychiatry, 157, 1399-1405. https://doi.org/10.1176/appi.ajp.157.9.1399

Djupesland, P. G., Mahmoud, R. A., \& Messina, J. C. (2013). Accessing the brain: The nose may know the way. Journal of Cerebral Blood Flow and Metabolism, 33, 793-794. https://doi.org/10.1038/ jcbfm.2013.41

Doty, R. L. (2001). Olfaction. Annual Review of Psychology, 52, 423452. https://doi.org/10.1146/annurev.psych.52.1.423

Doty, R. L. (2012a). Olfaction in Parkinson's disease and related disorders. Neurobiology of Diseases, 46, 527-552. https://doi. org/10.1016/j.nbd.2011.10.026

Doty, R. L. (2012b). Olfactory dysfunction in Parkinson disease. Nature Reviews Neurology, 8, 329-339. https://doi.org/10.1038/ nrneurol.2012.80

Doty, R. L., Deems, D. A., \& Stellar, S. (1988). Olfactory dysfunction in parkinsonism: A general deficit unrelated to neurologic signs, disease stage, or disease duration. Neurology, 38, 1237. https://doi. org/10.1212/WNL.38.8.1237

Doty, R. L., Li, C., Mannon, L. J., \& Yousem, D. M. (1999). Olfactory dysfunction in multiple sclerosis: Relation to longitudinal changes in plaque numbers in central olfactory structures. Neurology, 53, 880-882. https://doi.org/10.1212/WNL.53.4.880

Doty, R. L., Shaman, P., \& Dann, M. (1984). Development of the university of Pennsylvania smell identification test: A standardized microencapsulated test of olfactory function. Physiology \& Behavior, 32, 489-502. https://doi.org/10.1016/0031-9384(84)90269-5

Drucker, D. J. (2003). Therapeutic potential of dipeptidyl peptidase IV inhibitors for the treatment of type 2 diabetes. Expert Opinion on Investigational Drugs, 12, 87-100. https://doi. org/10.1517/13543784.12.1.87

Duda, J. E. (2010). Olfactory system pathology as a model of Lewy neurodegenerative disease. Journal of the Neurological Sciences, 289, 49-54. https://doi.org/10.1016/j.jns.2009.08.042

Duda, J. E., Giasson, B. I., Chen, Q., Gur, T. L., Hurtig, H. I., Stern, M. B., ... Trojanowski, J. Q. (2000). Widespread nitration of pathological inclusions in neurodegenerative synucleinopathies. American Journal of Pathology, 157, 1439-1445. https://doi.org/10.1016/ S0002-9440(10)64781-5

Duda, J. E., Shah, U., Arnold, S. E., Lee, V. M.-Y., \& Trojanowski, J. Q. (1999). The expression of $\alpha-, \beta-$, and $\gamma$-Synucleins in olfactory mucosa from patients with and without neurodegenerative diseases. Experimental Neurology, 160, 515-522. https://doi.org/10.1006/ exnr.1999.7228 
Elizan, T. S., \& Casals, J. (1983). The viral hypothesis in Parkinsonism. Journal of Neural Transmission. Supplementum, 19, 75-88.

Eng, J., Kleinman, W. A., Singh, L., Singh, G., \& Raufman, J. P. (1992). Isolation and characterization of exendin-4, an exendin-3 analogue, from Heloderma suspectum venom: Further evidence for an exendin receptor on dispersed acini from guinea pig pancreas. Journal of Biological Chemistry, 267, 7402-7405.

Ezeh, P. I., Wellis, D. P., \& Scott, J. W. (1993). Organization of inhibition in the rat olfactory bulb external plexiform layer. Journal of Neurophysiology, 70, 263-274. https://doi.org/10.1152/ jn.1993.70.1.263

Fadool, D. A., \& Levitan, I. B. (1998). Modulation of olfactory bulb neuron potassium current by tyrosine phosphorylation. Journal of Neuroscience, 18, 6126-6137. https://doi.org/10.1523/ JNEUROSCI.18-16-06126.1998

Fadool, D. A., Tucker, K., \& Pedarzani, P. (2011). Mitral cells of the olfactory bulb perform metabolic sensing and are disrupted by obesity at the level of the Kv1.3 ion channel. PLOS ONE, 6, 10-12.

Fadool, D. A., Tucker, K., Perkins, R., Fasciani, G., Thompson, R. N., Parsons, A. D., ... Kaczmarek, L. K. (2004). Kv1.3 channel genetargeted deletion produces "Super-Smeller Mice" with altered glomeruli, interacting scaffolding proteins, and biophysics. Neuron, 41, 389-404. https://doi.org/10.1016/S0896-6273(03)00844-4

Faedo, A., Ficara, F., Ghiani, M., Aiuti, A., Rubenstein, J. L., \& Bulfone, A. (2002). Developmental expression of the T-box transcription factor T-bet/Tbx21 during mouse embryogenesis. Mechanisms of Development, 116, 157-160. https://doi.org/10.1016/ S0925-4773(02)00114-4

Fitzgerald, M. J. T., Gruener, G., \& Mtui, E. (2007). Clinical neuroanatomy and neuroscience. Philadelphia, PA: Elsevier Saunders

Fordyce, C. B., Jagasia, R., Zhu, X., \& Schlichter, L. C. (2005). Microglia Kv1.3 channels contribute to their ability to kill neurons. Journal of Neuroscience, 25, 7139-7149. https://doi.org/10.1523/ JNEUROSCI.1251-05.2005

Freundt, E. C., Maynard, N., Clancy, E. K., Roy, S., Bousset, L., Sourigues, Y., ... Brahic, M. (2012). Neuron-to-neuron transmission of $\alpha$-synuclein fibrils through axonal transport. Annals of Neurology, 72, 517-524. https://doi.org/10.1002/ana.23747

Frey, W. H. (2002). Bypassing the blood-brain barrier to deliver therapeutic agents to the brain and spinal cord. Drug Development \& Delivery, 2, 46-49.

Fukunaga, I., Berning, M., Kollo, M., Schmaltz, A., \& Schaefer, A. T. (2012). Two distinct channels of olfactory bulb output. Neuron, 75, 320-329. https://doi.org/10.1016/j.neuron.2012.05.017

George, S., Rey, N. L., Reichenbach, N., Steiner, J. A., \& Brundin, P. (2013). $\alpha$-Synuclein: The long distance runner. Brain Pathology, 23, 350-357. https://doi.org/10.1111/bpa.12046

Good, P. F., Hsu, A., Werner, P., Perl, D. P., \& Warren Olanow, C. (1998). Protein nitration in Parkinson's disease. Journal of Neuropathology and Experimental Neurology, 57, 338-342. https:// doi.org/10.1097/00005072-199804000-00006

Gulbins, E., Sassi, N., Grassmè, H., Zoratti, M., \& Szabò, I. (2010). Role of Kv1.3 mitochondrial potassium channel in apoptotic signalling in lymphocytes. Biochimica et Biophysica Acta (BBA) - Bioenergetics, 1797, 1251-1259. https://doi.org/10.1016/j.bbabio.2010.01.018

Hanson, L. R., \& Frey, W. H. (2008). Intranasal delivery bypasses the blood-brain barrier to target therapeutic agents to the central nervous system and treat neurodegenerative disease. BMC Neuroscience, 9(Suppl 3), S5. https://doi.org/10.1186/1471-2202-9-S3-S5
Harkavyi, A., Abuirmeileh, A., Lever, R., Kingsbury, A. E., Biggs, C. S., \& Whitton, P. S. (2008). Glucagon-like peptide 1 receptor stimulation reverses key deficits in distinct rodent models of Parkinson's disease. Journal of Neuroinflammation, 5, 1-9.

Hawkes, C. H. (1999). Is Parkinson's disease a primary olfactory disorder? QJM: Monthly Journal of the Association of Physicians, 92, 473-480. https://doi.org/10.1093/qjmed/92.8.473

Hawkes, C. H., Del Tredici, K., \& Braak, H. (2007). Parkinson's disease: A dual-hit hypothesis. Neuropathology and Applied Neurobiology, 33, 599-614. https://doi.org/10.1111/j.1365-2990.2007.00874.x

Hawkes, C. H., Del Tredici, K., \& Braak, H. (2009). Parkinson's disease: The dual hit theory revisited. Annals of the New York Academy of Sciences, 1170, 615-622. https://doi. org/10.1111/j.1749-6632.2009.04365.x

Hawkes, C. H., Del Tredici, K., \& Braak, H. (2010). A timeline for Parkinson's disease. Parkinsonism \& Related Disorders, 16, 79-84. https://doi.org/10.1016/j.parkreldis.2009.08.007

Henry, R. R., Rosenstock, J., Denham, D. S., Prabhakar, P., Kjems, L., \& Baron, M. A. (2018). Clinical Impact of ITCA 650, a novel drug-device GLP-1 receptor agonist, in uncontrolled type 2 diabetes and very high baseline HbA 1c: The FREEDOM-1 HBL (High Baseline) study. Diabetes Care, 41, 613-619. https://doi. org/10.2337/dc17-1519

Henry, R. R., Rosenstock, J., Logan, D., Alessi, T., Luskey, K., \& Baron, M. A. (2014). Continuous subcutaneous delivery of exenatide via ITCA 650 leads to sustained glycemic control and weight loss for 48 weeks in metformin-treated subjects with type 2 diabetes. Journal of Diabetes and its Complications, 28, 393-398. https://doi. org/10.1016/j.jdiacomp.2013.12.009

Herskovits, A. Z., \& Guarente, L. (2014). SIRT1 in neurodevelopment and brain senescence. Neuron, 81, 471-483. https://doi. org/10.1016/j.neuron.2014.01.028

Hildebrand, C., Remahl, S., Persson, H., \& Bjartmar, C. (1993). Myelinated nerve fibres in the CNS. Progress in Neurobiology, 40, 319-384. https://doi.org/10.1016/0301-0082(93)90015-K

Hinds, J. W. (1968). Autoradiographic study of histogenesis in the mouse olfactory bulb I. Time of origin of neurons and neuroglia. Journal of Comparative Neurology, 134, 287-304. https://doi.org/10.1002/ (ISSN)1096-9861

Hirano, S., \& Takeichi, M. (2012). Cadherins in brain morphogenesis and wiring. Physiological Reviews, 92, 597-634. https://doi. org/10.1152/physrev.00014.2011

Höhn, A., Jung, T., Grimm, S., \& Grune, T. (2010). Lipofuscin-bound iron is a major intracellular source of oxidants: Role in senescent cells. Free Radical Biology and Medicine, 48, 1100-1108. https:// doi.org/10.1016/j.freeradbiomed.2010.01.030

Holst, J. J. (2007). The physiology of glucagon-like peptide 1 . Physiological Reviews, 87, 1409-1439. https://doi.org/10.1152/ physrev.00034.2006

Huang, L., Garcia, I., Jen, H.-I., \& Arenkiel, B. R. (2013). Reciprocal connectivity between mitral cells and external plexiform layer interneurons in the mouse olfactory bulb. Frontiers in Neural Circuits, 7, 1-16.

Huisman, E., Uylings, H. B. M., \& Hoogland, P. V. (2004). A 100\% increase of dopaminergic cells in the olfactory bulb may explain Hyposmia in Parkinson's disease. Movement Disorders, 19, 687692. https://doi.org/10.1002/mds.10713

Huisman, E., Uylings, H. B. M., \& Hoogland, P. V. (2008). Genderrelated changes in increase of dopaminergic neurons in the olfactory 
bulb of Parkinson's disease patients. Movement Disorders, 23, 1407-1413. https://doi.org/10.1002/mds.22009

Igarashi, K. M., Ieki, N., An, M., Yamaguchi, Y., Nagayama, S., Kobayakawa, K., ... Mori, K. (2012). Parallel mitral and tufted cell pathways route distinct odor information to different targets in the olfactory cortex. Journal of Neuroscience, 32, 7970-7985. https:// doi.org/10.1523/JNEUROSCI.0154-12.2012

Imamura, F., Ayoub, A. E., Rakic, P., \& Greer, C. A. (2011). Timing of neurogenesis is a determinant of olfactory circuitry. Nature Neuroscience, 14, 331-337. https://doi.org/10.1038/nn.2754

Isacson, R., Nielsen, E., Dannaeus, K., Bertilsson, G., Patrone, C., Zachrisson, O., \& Wikström, L. (2011). The glucagon-like peptide 1 receptor agonist exendin-4 improves reference memory performance and decreases immobility in the forced swim test. European Journal of Pharmacology, 650, 249-255. https://doi.org/10.1016/j.ejphar.2010.10.008

Iwai, T., Ito, S., Tanimitsu, K., Udagawa, S., \& Oka, J. I. (2006). Glucagon-like peptide-1 inhibits LPS-induced IL-1 $\beta$ production in cultured rat astrocytes. Neuroscience Research, 55, 352-360. https:// doi.org/10.1016/j.neures.2006.04.008

Kahoud, R. J., Elsen, G. E., Hevner, R. F., \& Hodge, R. D. (2014). Conditional ablation of Tbr2 results in abnormal development of the olfactory bulbs and subventricular zone-rostral migratory stream. Developmental Dynamics, 243, 440-450. https://doi.org/10.1002/dvdy.24090

Kalia, L. V., \& Lang, A. E. (2015). Parkinson's disease. Lancet, 386, 896-912. https://doi.org/10.1016/S0140-6736(14)61393-3

Kang, M. Y., Oh, T. J., \& Cho, Y. M. (2015). Glucagon-like peptide-1 increases mitochondrial biogenesis and function in INS-1 rat insulinoma cells. Endocrinology and Metabolism (Seoul, Korea), 30, 216-220. https://doi.org/10.3803/EnM.2015.30.2.216

Kebschull, J. M., Garcia da Silva, P., Reid, A. P., Peikon, I. D., Albeanu, D. F., \& Zador, A. M. (2016). High-throughput mapping of singleneuron projections by sequencing of barcoded RNA. Neuron, 91, 975-987. https://doi.org/10.1016/j.neuron.2016.07.036

Khaing, Z. Z., Thomas, R. C., Geissler, S. A., \& Schmidt, C. E. (2014). Advanced biomaterials for repairing the nervous system: What can hydrogels do for the brain? Biochemical Pharmacology, 17, 332-340.

Kieffer, T. J., McIntosh, C. H., \& Pederson, R. A. (1995). Degradation of glucose-dependent insulinotropic polypeptide and truncated glucagon-like peptide 1 in vitro and in vivo by dipeptidyl peptidase IV. Endocrinology, 136, 3585-3596. https://doi.org/10.1210/ endo.136.8.7628397

Kim, S., Moon, M., \& Park, S. (2009). Exendin-4 protects dopaminergic neurons by inhibition of microglial activation and matrix metalloproteinase-3 expression in an animal model of Parkinson's disease. Journal of Endocrinology, 202, 431-439. https://doi.org/10.1677/JOE-09-0132

Kimura, N., Nakashima, K., Ueno, M., Kiyama, H., \& Taga, T. (1999). A novel mammalian T-box-containing gene, Tbr2, expressed in mouse developing brain. Developmental Brain Research, 115, 183193. https://doi.org/10.1016/S0165-3806(99)00064-4

Kimura, R., Okouchi, M., Fujioka, H., Ichiyanagi, A., Ryuge, F., Mizuno, T., ... Joh, T. (2009). Glucagon-like peptide-1 (GLP1) protects against methylglyoxal-induced $\mathrm{PC} 12$ cell apoptosis through the PI3K/Akt/mTOR/GCLc/redox signaling pathway. Neuroscience, 162, 1212-1219. https://doi.org/10.1016/j. neuroscience.2009.05.025

Kishi, K., Mori, K., \& Ojima, H. (1984). Distribution of local axon collaterals of mitral, displaced mitral, and tufted cells in the rabbit olfactory bulb. Journal of Comparative Neurology, 225, 511-526. https://doi.org/10.1002/(ISSN)1096-9861
Koeberle, P. D., \& Schlichter, L. C. (2010). Targeting K(V) channels rescues retinal ganglion cells in vivo directly and by reducing inflammation. Channels (Austin), 4, 337-346. https://doi.org/10.4161/chan.4.5.12790

Kordower, J. H., Chu, Y., Hauser, R. A., Freeman, T. B., \& Olanow, C. W. (2008). Lewy body-like pathology in long-term embryonic nigral transplants in Parkinson's disease. Nature Medicine, 14, 504-506. https://doi.org/10.1038/nm1747

Kosaka, T., \& Kosaka, K. (2016). Neuronal organization of the main olfactory bulb revisited. Anatomical Science International, 91, 115127. https://doi.org/10.1007/s12565-015-0309-7

Kovach, C. P., Al Koborssy, D., Huang, Z., Chelette, B. M., Fadool, J. M., \& Fadool, D. A. (2016). Mitochondrial ultrastructure and glucose signaling pathways attributed to the Kv1.3 ion channel. Frontiers in Physiology, 7, 1-15.

Lalancette-Hbert, M., Phaneuf, D., Soucy, G., Weng, Y. C., \& Kriz, J. (2009). Live imaging of toll-like receptor 2 response in cerebral Ischaemia reveals a role of olfactory bulb microglia as modulators of inflammation. Brain, 132, 940-954. https://doi.org/10.1093/brain/awn345

Larsen, P. J. (1997). Central administration of glucagon-like peptide-1 activates hypothalamic neuroendocrine neurons in the rat. Endocrinology, 138, 4445-4455. https://doi.org/10.1210/endo.138.10.5270

Lawson, L. J., Perry, V. H., Dri, P., \& Gordon, S. (1990). Heterogeneity in the distribution and morphology of microglia in the normal adult mouse brain. Neuroscience, 39, 151-170. https://doi. org/10.1016/0306-4522(90)90229-W

Lee, J., Hong, S. W., Park, S. E. U., Rhee, E. J., Park, C. Y., Oh, K. W., ... Lee, W. Y. (2014). Exendin-4 attenuates endoplasmic reticulum stress through a SIRT1-dependent mechanism. Cell Stress and Chaperones, 19, 649-656. https://doi.org/10.1007/s12192-013-0490-3

Lennox, R., Porter, D. W., Flatt, P. R., Holscher, C., Irwin, N., \& Gault, V. A. (2014). Comparison of the independent and combined effects of sub-chronic therapy with metformin and a stable GLP-1 receptor agonist on cognitive function, hippocampal synaptic plasticity and metabolic control in high-fat fed mice. Neuropharmacology, 86, 22-30. https://doi.org/10.1016/j.neuropharm.2014.06.026

Levesque, S., Surace, M. J., McDonald, J., \& Block, M. L. (2011). Air pollution and the brain: Subchronic diesel exhaust exposure causes neuroinflammation and elevates early markers of neurodegenerative disease. Journal of Neuroinflammation, 8, 1-10.

Li, J. Y., Englund, E., Holton, J. L., Soulet, D., Hagell, P., Lees, A. J., ... Brundin, P. (2008). Lewy bodies in grafted neurons in subjects with Parkinson's disease suggest host-to-graft disease propagation. Nature Medicine, 14, 501-503. https://doi.org/10.1038/nm1746

Li, H., Jia, Z., Li, G., Zhao, X., Sun, P., Wang, J., ... Lv, G. (2015). Neuroprotective effects of exendin-4 in rat model of spinal cord injury via inhibiting mitochondrial apoptotic pathway. International Journal of Clinical and Experimental Pathology, 8, 4837-4843.

Li, H., Lee, C. H., Yoo, K.-Y., Choi, J. H., Park, O. K., Yan, B. C., ... Won, M.-H. (2010). Chronic treatment of exendin-4 affects cell proliferation and neuroblast differentiation in the adult mouse hippocampal dentate gyrus. Neuroscience Letters, 486, 38-42. https:// doi.org/10.1016/j.neulet.2010.09.040

Liu, W., Jalewa, J., Sharma, M., Li, G., Li, L., \& Hölscher, C. (2015). Neuroprotective effects of lixisenatide and liraglutide in the 1-meth yl-4-phenyl-1,2,3,6-tetrahydropyridine mouse model of Parkinson's disease. Neuroscience, 303, 42-50. https://doi.org/10.1016/j. neuroscience.2015.06.054

Liu, J., Yin, F., Zheng, X., Jing, J., \& Hu, Y. (2007). Geniposide, a novel agonist for GLP-1 receptor, prevents PC12 cells from oxidative 
damage via MAP kinase pathway. Neurochemistry International, 51, 361-369. https://doi.org/10.1016/j.neuint.2007.04.021

Luciani, P., Deledda, C., Benvenuti, S., Cellai, I., Squecco, R., Monici, M., ... Peri, A. (2010). Differentiating effects of the glucagon-like peptide-1 analogue exendin-4 in a human neuronal cell model. Cellular and Molecular Life Sciences, 67, 3711-3723. https://doi. org/10.1007/s00018-010-0398-3

Ma, J., Dankulich-Nagrudny, L., \& Lowe, G. (2013). Cholecystokinin: An excitatory modulator of mitral/tufted cells in the mouse olfactory bulb. PLoS ONE, 8, e64170. https://doi.org/10.1371/journal. pone. 0064170

Macklis, J. D. (2012). Human adult olfactory bulb neurogenesis? Novelty is the best policy. Neuron, 74, 595-596. https://doi.org/10.1016/j. neuron.2012.05.005

Macrides, F., \& Schneider, S. P. (1982). Laminar organization of mitral and tufted cells in the main olfactory bulb of the adult hamster. Journal of Comparative Neurology, 208, 419-430. https://doi. org/10.1002/(ISSN)1096-9861

Maheu, M. E., Devorak, J., Freibauer, A., Davoli, M. A., Turecki, G., \& Mechawar, N. (2015). Increased doublecortin (DCX) expression and incidence of DCX-immunoreactive multipolar cells in the subventricular zone-olfactory bulb system of suicides. Frontiers in Neuroanatomy, 9, 74.

Mason, D. M., Nouraei, N., Pant, D. B., Miner, K. M., Hutchison, D. F., Luk, K. C., ... Leak, R. K. (2016). Transmission of $\alpha-$ synucleinopathy from olfactory structures deep into the temporal lobe. Molecular Neurodegeneration, 11, 49. https://doi.org/10.1186/ s13024-016-0113-4

Masurkar, A. V., \& Chen, W. R. (2009). Olfactory Bulb Physiology. In M. D. Binder, N. Hirokawa \& U. Windhorst (Eds.), Encyclopedia of neuroscience (pp. 77-86). Berlin, Germany: Elsevier.

Menalled, L. B., Sison, J. D., Dragatsis, I., Zeitlin, S., \& Chesselet, M. F. (2003). Time course of early motor and neuropathological anomalies in a knock-in mouse model of Huntington's disease with 140 CAG repeats. Journal of Comparative Neurology, 465, 11-26. https://doi.org/10.1002/(ISSN)1096-9861

Méndez-Gómez, H. R., Vergaño-Vera, E., Abad, J. L., Bulfone, A., Moratalla, R., de Pablo, F., \& Vicario-Abejón, C. (2011). The Tbox brain 1 (Tbr1) transcription factor inhibits astrocyte formation in the olfactory bulb and regulates neural stem cell fate. Molecular and Cellular Neurosciences, 46, 108-121. https://doi.org/10.1016/j. men.2010.08.011

Merchenthaler, I., Lane, M., \& Shughrue, P. (1999). Distribution of prepro-glucagon and glucagon-like peptide-1 receptor messenger RNAs in the rat central nervous system. Journal of Comparative Neurology, 403, 261-280. https://doi.org/10.1002/(ISSN)1096-9861

Merkus, P., Guchelaar, H.-J., Bosch, D. A., \& Merkus, F. W. H. M. (2003). Direct access of drugs to the human brain after intranasal drug administration? Neurology, 60, 1669-1671. https://doi. org/10.1212/01.WNL.0000067993.60735.77

Merkus, F. W., Verhoef, J. C., Schipper, N. G., \& Marttin, E. (1998). Nasal mucociliary clearance as a factor in nasal drug delivery. Advanced Drug Delivery Reviews, 29, 13-38.

Mihalas, A. B., \& Hevner, R. F. (2017). Control of Neuronal Development by T-Box Genes in the Brain. In M. Frash (Ed.), Tbox genes in development and disease, 1st edn. (pp. 279-312) San Diego, CA: Elsevier Inc.

Mitsui, S., Igarashi, K. M., Mori, K., \& Yoshihara, Y. (2011). Genetic visualization of the secondary olfactory pathway in Tbx21 transgenic mice. Neural Systems \& Circuits, 1, 5. https://doi. org/10.1186/2042-1001-1-5

Miyake, M. M., \& Bleier, B. S. (2015). The blood-brain barrier and nasal drug delivery to the central nervous system. American Journal of Rhinology \& Allergy, 29, 124-127. https://doi.org/10.2500/ ajra.2015.29.4149

Mori, I. (2017). Viremic attack explains the dual-hit theory of Parkinson's disease. Medical Hypotheses, 101, 33-36. https://doi. org/10.1016/j.mehy.2017.02.007

Morrison, E. E., \& Costanzo, R. M. (1992). Morphology of olfactory epithelium in humans and other vertebrates. Microscopy Research and Technique, 23, 49-61. https://doi.org/10.1002/(ISSN)1097-0029

Mullard, A. (2014). Once-yearly device takes on daily and weekly diabetes drugs. Nature Biotechnology, 32, 1178. https://doi.org/10.1038/ nbt1214-1178

Mundiñano, I. C., Caballero, M. C., Ordóñez, C., Hernandez, M., DiCaudo, C., Marcilla, I., ... Luquin, M. R. (2011). Increased dopaminergic cells and protein aggregates in the olfactory bulb of patients with neurodegenerative disorders. Acta Neuropathologica, 122, 61-74. https://doi.org/10.1007/s00401-011-0830-2

Nagai, Y., Sano, H., \& Yokoi, M. (2005). Transgenic expression of Cre recombinase in mitral/tufted cells of the olfactory bulb. Genesis, 43, 12-16. https://doi.org/10.1002/(ISSN)1526-968X

Nagayama, S., Homma, R., \& Imamura, F. (2014). Neuronal organization of olfactory bulb circuits. Frontiers in Neural Circuits, 8, 1-19.

Nakajima, D., Nakayama, M., Kikuno, R., Hirosawa, M., Nagase, T., \& Ohara, O. (2001). Identification of three novel non-classical cadherin genes through comprehensive analysis of large cDNAs. Molecular Brain Research, 94, 85-95. https://doi.org/10.1016/ S0169-328X(01)00218-2

Ohtake, N., Saito, M., Eto, M., \& Seki, K. (2014). Exendin-4 promotes the membrane trafficking of the AMPA receptor GluR1 subunit and ADAM10 in the mouse neocortex. Regulatory Peptides, 190-191, 1-11. https://doi.org/10.1016/j.regpep.2014.04.003

Olanow, C. W., \& Prusiner, S. B. (2009). Is Parkinson's disease a prion disorder? Proceedings of the National Academy of Sciences of the United States of America, 106, 12571-12572. https://doi. org/10.1073/pnas.0906759106

Orona, E., Rainer, E. C., \& Scott, J. W. (1984). Dendritic and axonal organization of mitral and tufted cells in the rat olfactory bulb. Journal of Comparative Neurology, 226, 346-356. https://doi.org/10.1002/ (ISSN)1096-9861

Pager, J., Giachetti, I., Holley, A., \& Le Magnen, J. (1972). A selective control of olfactory bulb electrical activity in relation to food deprivation and satiety in rats. Physiology \& Behavior, 9, 573-579. https://doi.org/10.1016/0031-9384(72)90014-5

Paik, S. R., Shin, H. J., Lee, J. H., Chang, C. S., \& Kim, J. (1999). Copper(II)induced self-oligomerization of alpha-synuclein. Biochemical Journal, 340(Pt 3), 821-828. https://doi.org/10.1042/bj3400821

Papaioannou, V. E. (2014). The T-box gene family: Emerging roles in development, stem cells and cancer. Development, 141, 3819-3833. https://doi.org/10.1242/dev.104471

Park, S. C., Moon, J. C., Shin, S. Y., Son, H., Jung, Y. J., Kim, N. H., ... Lee, J. R. (2016). Functional characterization of alpha-synuclein protein with antimicrobial activity. Biochemical and Biophysical Research Communications, 478, 924-928. https://doi.org/10.1016/j. bbrc.2016.08.052

Parkes, D. G., Mace, K. F., \& Trautmann, M. E. (2013). Discovery and development of exenatide: The first antidiabetic agent to leverage the 
multiple benefits of the incretin hormone, GLP-1. Expert Opinion on Drug Discovery, 8, 219-244. https://doi.org/10.1517/17460441 .2013 .741580

Pearce, R. K. B., Hawkes, C. H., \& Daniel, S. E. (1995). The anterior olfactory nucleus in Parkinson's disease. Movement Disorders, 10, 283-287. https://doi.org/10.1002/(ISSN)1531-8257

Perry, T., Haughey, N. J., Mattson, M. P., Egan, J. M., \& Greig, N. H. (2002). Protection and reversal of excitotoxic neuronal damage by glucagon-like peptide-1 and exendin-4. Journal of Pharmacology and Experimental Therapeutics, 302, 881-888. https://doi. org/10.1124/jpet.102.037481

Perry, T., Lahiri, D. K., Chen, D., Zhou, J., Shaw, K. T. Y., Egan, J. M., \& Greig, N. H. (2002). A novel neurotrophic property of glucagon-like peptide 1: A promoter of nerve growth factormediated differentiation in PC12 cells. Journal of Pharmacology and Experimental Therapeutics, 300, 958-966. https://doi. org/10.1124/jpet.300.3.958

Perry, T., Lahiri, D. K., Sambamurti, K., Chen, D., Mattson, M. P., Egan, J. M., \& Greig, N. H. (2003). Glucagon-like peptide-1 decreases endogenous amyloid-beta peptide (Abeta) levels and protects hippocampal neurons from death induced by Abeta and iron. Journal of Neuroscience Research, 72, 603-612. https://doi.org/10.1002/(ISSN)1097-4547

Perry, C., Mackay-Sim, A., Feron, F., \& McGrath, J. (2002). Olfactory neural cells: An untapped diagnostic and therapeutic resource. Laryngoscope, 112, 603-607. https://doi. org/10.1097/00005537-200204000-00002

Qin, Z., Sun, Z., Huang, J., Hu, Y., Wu, Z., \& Mei, B. (2008). Mutated recombinant human glucagon-like peptide-1 protects SH-SY5Y cells from apoptosis induced by amyloid- $\beta$ peptide (1-42). Neuroscience Letters, 444, 217-221. https://doi.org/10.1016/j.neulet.2008.08.047

Rangaraju, S., Gearing, M., Jin, L.-W., \& Levey, A. (2015). Potassium channel Kv1.3 is highly expressed by microglia in human Alzheimer's disease. Journal of Alzheimer's Disease, 44, 797-808. https://doi.org/10.3233/JAD-141704

Rey, N. L., George, S., Steiner, J. A., Madaj, Z., Luk, K. C., Trojanowski, J. Q., ... Brundin, P. (2018). Spread of aggregates after olfactory bulb injection of $\alpha$-synuclein fibrils is associated with early neuronal loss and is reduced long term. Acta Neuropathologica, 135, 65-83. https://doi.org/10.1007/s00401-017-1792-9

Rey, N. L., Petit, G. H., Bousset, L., Melki, R., \& Brundin, P. (2013). Transfer of human alpha-synuclein from the olfactory bulb to interconnected brain regions in mice. Acta Neuropathologica, 126, 555-573. https://doi.org/10.1007/s00401-013-1160-3

Rey, N. L., Steiner, J. A., Maroof, N., Luk, K. C., Madaj, Z., Trojanowski, J. Q., ... Brundin, P. (2016). Widespread transneuronal propagation of $\alpha$-synucleinopathy triggered in olfactory bulb mimics prodromal Parkinson's disease. Journal of Experimental Medicine, 213, 17591778. https://doi.org/10.1084/jem.20160368

Rey, N. L., Wesson, D. W., \& Brundin, P. (2018). The olfactory bulb as the entry site for prion-like propagation in neurodegenerative diseases. Neurobiology of Diseases, 109, 226-248. https://doi. org/10.1016/j.nbd.2016.12.013

Rocha, N. P., Reis, H. J., Vanden Berghe, P., \& Cirillo, C. (2014). Depression and cognitive impairment in Parkinson's disease: A role for inflammation and immunomodulation? NeuroImmunoModulation, 21, 88-94. https://doi. org/10.1159/000356531

Rosenstock, J., Buse, J. B., Azeem, R., Prabhakar, P., Kjems, L., Huang, H., \& Baron, M. A. (2018). Efficacy and safety of ITCA 650, a novel drug-device GLP-1 receptor agonist, in type 2 diabetes uncontrolled with oral Antidiabetes drugs: The FREEDOM-1 trial. Diabetes Care, 41, 333-340. https://doi.org/10.2337/dc17-1306

Ruberte, J., Navarro, M., König, H. E., \& Puelles, L. (2017). Nervous system. In J. Ruberte, A. Carretero \& M. Navarro (Eds.), Morphological Mouse - Phenotyping Anatomy, Histology and Imaging (pp. 600). Madrid, Spain: Editorial Medica Panamericana.

Salcedo, I., Tweedie, D., Li, Y., \& Greig, N. H. (2012). Neuroprotective and neurotrophic actions of glucagon-like peptide-1: An emerging opportunity to treat neurodegenerative and cerebrovascular disorders. British Journal of Pharmacology, 166, 1586-1599. https://doi. org/10.1111/j.1476-5381.2012.01971.x

Sampaio-Marques, B., Felgueiras, C., Silva, A., Rodrigues, M., Tenreiro, S., Franssens, V., ... Ludovico, P. (2012). SNCA ( $\alpha$ synuclein)-induced toxicity in yeast cells is dependent on sirtuin 2 (Sir2)-mediated mitophagy. Autophagy, 8, 1494-1509. https://doi. org/10.4161/auto.21275

Satou, M. (1990). Synaptic organization, local neuronal circuitry, and functional segregation of the teleost olfactory bulb. Progress in Neurobiology, 34, 115-142. https://doi. org/10.1016/0301-0082(90)90004-Z

Sengoku, R., Saito, Y., Ikemura, M., Hatsuta, H., Sakiyama, Y., Kanemaru, K., ... Murayama, S. (2008). Incidence and extent of Lewy body-related alpha-synucleinopathy in aging human olfactory bulb. Journal of Neuropathology and Experimental Neurology, 67, 1072-1083. https://doi.org/10.1097/ NEN.0b013e31818b4126

Serby, M., Larson, P., \& Kalkstein, D. (1991). The nature and course of olfactory deficits in Alzheimer's disease. American Journal of Psychiatry, 148, 357-360.

Sharma, S. K., Chorell, E., Steneberg, P., Vernersson-Lindahl, E., Edlund, H., \& Wittung-Stafshede, P. (2015). Insulin-degrading enzyme prevents $\alpha$-synuclein fibril formation in a nonproteolytical manner. Scientific Reports, 5, 1-10.

Sharma, A. N., Ligade, S. S., Sharma, J. N., Shukla, P., Elased, K. M., \& Lucot, J. B. (2015). GLP-1 receptor agonist liraglutide reverses long-term atypical antipsychotic treatment associated behavioral depression and metabolic abnormalities in rats. Metabolic Brain Disease, 30, 519-527. https://doi.org/10.1007/s11011-014-9591-7

Shepherd, G. M., Chen, W. R., \& Greer, C. A. (2013). Olfactory Bulb. In G. M. Shepherd (Ed.), The synaptic organization of the brain (pp. 165-217). Oxford, UK: Oxford University Press, Inc.

Silva, A. M., Santos, E., Moreira, I., Bettencourt, A., Coutinho, E., Gonçalves, A., ... Cavaco, S. (2012). Olfactory dysfunction in multiple sclerosis: Association with secondary progression. Multiple Sclerosis Journal, 18, 616-621. https://doi. org/10.1177/1352458511427156

Spielman, L. J., Gibson, D. L., \& Klegeris, A. (2017). Incretin hormones regulate microglia oxidative stress, survival and expression of trophic factors. European Journal of Cell Biology, 96, 240-253. https://doi.org/10.1016/j.ejcb.2017.03.004

Steiner, J. A., Quansah, E., \& Brundin, P. (2018). The concept of alphasynuclein as a prion-like protein: Ten years after. Cell and Tissue Research,373, 161-173. https://doi.org/10.1007/s00441-018-2814-1

Storace, D. A., \& Cohen, L. B. (2017). Measuring the olfactory bulb input-output transformation reveals a contribution to the perception of odorant concentration invariance. Nature Communications, 8, 1-10.

Szabó, I., Bock, J., Grassmé, H., Soddemann, M., Wilker, B., Lang, F., ... Gulbins, E. (2008). Mitochondrial potassium channel Kv1.3 
mediates Bax-induced apoptosis in lymphocytes. Proceedings of the National Academy of Sciences of the United States of America, 105, 14861-14866. https://doi.org/10.1073/pnas.0804236105

Tarkun, I. (2014). Exenatide treatment exerts anxiolytic- and antidepressantlike effects and reverses neuropathy in a mouse model of type- 2 diabetes. Medical Science Monitor Basic Research, 20, 112-117.

Thiebaud, N., Llewellyn-Smith, I. J., Gribble, F., Reimann, F., Trapp, S., $\&$ Fadool, D. A. (2016). The incretin hormone glucagon-like peptide 1 increases mitral cell excitability by decreasing conductance of a voltage-dependent potassium channel. Journal of Physiology, 594, 2607-2628. https://doi.org/10.1113/JP272322

Thomas, M. P., Chartrand, K., Reynolds, A., Vitvitsky, V., Banerjee, R., \& Gendelman, H. E. (2007). Ion channel blockade attenuates aggregated alpha synuclein induction of microglial reactive oxygen species: Relevance for the pathogenesis of Parkinson's disease. Journal of Neurochemistry, 100, 503-519. https://doi. org/10.1111/j.1471-4159.2006.04315.x

Thomas, D., Fontana, G., Chen, X., Sanz-Nogués, C., Zeugolis, D. I., Dockery, P., ... Pandit, A. (2014). A shape-controlled tuneable microgel platform to modulate angiogenic paracrine responses in stem cells. Biomaterials, 35, 8757-8766. https://doi.org/10.1016/j. biomaterials.2014.06.053

Tomlinson, J. J., Shutinoski, B., Dong, L., Meng, F., Elleithy, D., Lengacher, N. A., .. Schlossmacher, M. G. (2017). Holocranohistochemistry enables the visualization of $\alpha$-synuclein expression in the murine olfactory system and discovery of its systemic anti-microbial effects. Journal of Neural Transmission, 124, 721-738. https://doi.org/10.1007/s00702-017-1726-7

Ubeda-Bañon, I., Saiz-Sanchez, D., De La Rosa-Prieto, C., ArgandoñaPalacios, L., Garcia-Muñozguren, S., \& Martinez-Marcos, A. (2010). $\alpha$-Synucleinopathy in the human olfactory system in Parkinson's disease: Involvement of calcium-binding protein- and substance P-positive cells. Acta Neuropathologica, 119, 723-735. https://doi.org/10.1007/s00401-010-0687-9

Ubeda-Bañon, I., Saiz-Sanchez, D., De La Rosa-Prieto, C., \& MartinezMarcos, A. (2012). $\alpha$-Synuclein in the olfactory system of a mouse model of Parkinson's disease: Correlation with olfactory projections. Brain Structure \& Function, 217, 447-458. https://doi.org/10.1007/ s00429-011-0347-4

Ubeda-Bañon, I., Saiz-Sanchez, D., De La Rosa-Prieto, C., \& Martinez-Marcos, A. (2014). $\alpha$-Synuclein in the olfactory system in Parkinson's disease: Role of neural connections on spreading pathology. Brain Structure \& Function, 219, 1513-1526.

Ubeda-Bañon, I., Saiz-Sanchez, D., de la Rosa-Prieto, C., MohedanoMoriano, A., Fradejas, N., Calvo, S., ... Martinez-Marcos, A. (2010). Staging of alpha-synuclein in the olfactory bulb in a model of Parkinson's disease: Cell types involved. Movement Disorders, 25, 1701-1707. https://doi.org/10.1002/mds.23197

Ventorp, F., Bay-Richter, C., Nagendra, A. S., Janelidze, S., Matsson, V. S., Lipton, J., ... Brundin, L. (2017). Exendin-4 treatment improves LPS-induced depressive-like behavior without affecting pro-inflammatory cytokines. Journal of Parkinson's Disease, 7, 263-273. https://doi.org/10.3233/JPD-171068

Vrang, N., \& Larsen, P. J. (2010). Preproglucagon derived peptides GLP-1, GLP-2 and oxyntomodulin in the CNS: Role of peripherally secreted and centrally produced peptides. Progress in Neurobiology, 92, 442-462. https://doi.org/10.1016/j.pneurobio.2010.07.003

Wang, J., Eslinger, P. J., Doty, R. L., Zimmerman, E. K., Grunfeld, R., Sun, X., ... Yang, Q. X. (2010). Olfactory deficit detected by fMRI in early Alzheimer's disease. Brain Research, 1357, 184-194. https://doi.org/10.1016/j.brainres.2010.08.018

Wilson, V., \& Conlon, F. L. (2002). The T-box family. Genome Biology, 3, 3008.1-3008.7.

Winpenny, E., Lebel-Potter, M., Fernandez, M. E., Brill, M. S., Götz, M., Guillemot, F., \& Raineteau, O. (2011). Sequential generation of olfactory bulb glutamatergic neurons by Neurog2expressing precursor cells. Neural Development, 6, 12. https://doi. org/10.1186/1749-8104-6-12

Xu, W., Yang, Y., Yuan, G., Zhu, W., Ma, D., \& Hu, S. (2015). Exendin-4, a glucagon-like peptide-1 receptor agonist, reduces alzheimer disease-associated tau hyperphosphorylation in the hippocampus of rats with type 2 diabetes. Journal of Investigative Medicine, 63, 267-272. https://doi.org/10.1097/JIM.0000000000000129

Yang, M. J., Sim, S., Jeon, J. H., Jeong, E., Kim, H. C., Park, Y. J., \& Kim, I. B. (2013). Mitral and tufted cells are potential cellular targets of nitration in the olfactory bulb of aged mice. PLOS ONE, 8, 1-11.

Yoshihara, S. I. (2005). Arx homeobox gene is essential for development of mouse olfactory system. Development, 132, 751-762. https://doi. org/10.1242/dev.01619

Yusta, B., Baggio, L. L., Estall, J. L., Koehler, J. A., Holland, D. P., Li, H., ... Drucker, D. J. (2006). GLP-1 receptor activation improves $\beta$ cell function and survival following induction of endoplasmic reticulum stress. Cell Metabolism, 4, 391-406. https://doi.org/10.1016/j. cmet.2006.10.001

Zivadinov, R., Zorzon, M., Monti Bragadin, L., Pagliaro, G., \& Cazzato, G. (1999). Olfactory loss in multiple sclerosis. Journal of the Neurological Sciences, 168, 127-130. https://doi.org/10.1016/ S0022-510X(99)00189-6

Zorzon, M., Ukmar, M., Bragadin, L. M., Zanier, F., Antonello, R. M., Cazzato, G., \& Zivadinov, R. (2000). Olfactory dysfunction and extent of white matter abnormalities in multiple sclerosis: A clinical and MR study. Multiple Sclerosis, 6, 386-390. https://doi. org/10.1177/135245850000600605

Zou, Y., Lu, D., Liu, L.-P., Zhang, H., \& Zhou, Y. (2016). Olfactory dysfunction in Alzheimer's disease. Neuropsychiatric Disease and Treatment, 12, 869-875. https://doi.org/10.2147/NDT

How to cite this article: Bagnoli E, FitzGerald U. Mitral cells and the glucagon-like peptide 1 receptor: The sweet smell of success?. Eur J Neurosci. 2018;00:1-18. https://doi.org/10.1111/ejn.14115 